\title{
Harnessing Strained Disulfides for Photocurable Adaptable Hydrogels
}

Georg M. Scheutz, ${ }^{1}$ Jonathan L. Rowell, ${ }^{1}$ S. Tori Ellison, ${ }^{2}$ John B. Garrison, ${ }^{1}$ Thomas E. Angelini, ${ }^{2,3,4,5}$ and Brent S. Sumerlin ${ }^{1, *}$

${ }^{1}$ George \& Josephine Butler Polymer Research Laboratory, Center for Macromolecular Science \& Engineering, Department of Chemistry, University of Florida, Gainesville, FL 32611, USA.

${ }^{2}$ Department of Material Sciences and Engineering, ${ }^{3}$ Department of Mechanical and Aerospace Engineering, ${ }^{4} \mathrm{~J}$. Crayton Pruitt Family Department of Biomedical Engineering, and ${ }^{5}$ Institute for Cell and Regenerative Medicine, University of Florida, Gainesville, FL 32611, USA.

S1. Materials

S2. Instrumentation

S3. Supplementary Figures

S4. Calculation of $E_{\mathrm{s}}$ and $E_{\mathrm{d}}$

S5. Procedures

S6. Supplementary NMR Spectra 26

S7. References 


\section{S1. Materials}

All materials were used as received unless otherwise noted. Poly(ethylene glycol) (PEG, $\left.M_{\mathrm{n}}=8000 \mathrm{~g} / \mathrm{mol}\right)$, bromine $\left(\mathrm{Br}_{2}\right)$, bromobenzene, magnesium turnings, potassium carbonate $\left(\mathrm{K}_{2} \mathrm{CO}_{3}\right)$, phenothiazine, 4-dimethylaminopyridine (DMAP), triethylamine (TEA), water (HPLC grade), Ellman's reagent (5,5'-dithiobis-(2-nitrobenzoic acid), DTNB), rhodamine 6G, and tetrabutylammonium tetrafluoroborate ( $\mathrm{TBABF}_{4}$, electrochemical grade) were purchased form Sigma-Aldrich. 1,3-Dichloroacetone, isobutyryl chloride, methyl acrylate (MA), 2-mercaptoethanol (MSH), and tert-butylthiol were purchased from ACROS Organics. Eosin Y (EY) was obtained from Santa Cruz Biotechnology. 1,4-Butanedithiol and dithiothreitol (DTT) were purchased from $\mathrm{TCl}$ America. Methanol $(\mathrm{MeOH})$, hexanes, N,N-dimethylformamide (DMF), diethyl ether $\left(\mathrm{Et}_{2} \mathrm{O}\right)$, and dichloromethane (DCM) were purchased from Fisher Scientific. All solvent mixtures are given in volume ratios. Silica gel (40-60 $\mu \mathrm{m}, 60 \AA)$ was obtained from VWR. Ethylene diamine (Sigma-Aldrich) was distilled under reduced pressure prior to use. 1,2Dithiane was synthesized according to a prior report. ${ }^{1}$ UV light $\left(4.6 \mathrm{~mW} / \mathrm{cm}^{2}\right)$ was supplied from a UV nail gel-curing lamp (available online from ad hoc suppliers) with four $9 \mathrm{~W}$ bulbs and a peak emission near $365 \mathrm{~nm}$ (Figure S22A). As the green light source, a photoreactor ${ }^{2}$ with a single LED chip was used giving a peak emission at $515 \mathrm{~nm}$ (Figure S22B). NIH-3t3 cells were cultured in Dulbecco's Modified Eagle Medium (DMEM) with 4.5g/L glucose, L-glutamine, and sodium pyruvate supplemented with $10 \%$ FBS and $1 \%$ penicillin streptomycin and dyed with cell tracker green (CMFDA) (Thermo-Fisher, part no. C2925). 


\section{S2. Instrumentation}

Nuclear Magnetic Resonance (NMR) Spectroscopy. ${ }^{1} \mathrm{H}$ NMR and ${ }^{13} \mathrm{C}$ NMR spectra were recorded on an INOVA $500 \mathrm{MHz}$ spectrometer. Chemical shifts $(\delta)$ are given in parts per million ( $\mathrm{ppm}$ ) relative to TMS and referenced to residual protonated solvent purchased from Cambridge Isotope Laboratories, Inc. (DMSO- $d_{6}: \delta^{1} \mathrm{H} 2.50$ ppm; $\mathrm{CDCl}_{3}: \delta^{1} \mathrm{H} 7.26$ ppm, $\delta^{13} \mathrm{C} 77.16 \mathrm{ppm}$ ). Abbreviations used are $\mathrm{s}$ (singlet), $\mathrm{d}$ (doublet), $\mathrm{t}$ (triplet), sept (septet), b (broad), and $\mathrm{m}$ (multiplet).

High Resolution Mass Spectrometry (HRMS). HRMS was conducted on an Agilent 6220 TOF spectrometer with electro spray ionization (ESI) (analyzed in positive mode).

Dynamic Light Scattering (DLS). DLS was performed with a Malvern Zetasizer Nano ZS (Model No. ZEN 3600, Malvern Instruments Ltd., Worcestershire UK).

Dry-State Transmission Electron Microscopy (TEM). TEM was conducted on a Tecnai G2 Spirit TWIN TEM from Field Electron and Ion Company (FEI Company, Hillsboro, OR, USA) operating at an accelerating voltage of $120 \mathrm{kV}$. Digital images were acquired with a Gatan Ultrascan 1000 2k $\times 2 k$ CCD camera and DigitalMicrograph 1.93 image acquisition software (Gatan Inc., Pleasanton, CA, USA.) Electron Microscopy Sciences Formvar Carbon Film on 400 mesh nickel grids (FCF400-Ni) were used for all trials. A nanoparticle solution $(5 \mu \mathrm{L}, 1 \mathrm{mg} / \mathrm{mL})$ was spotted on the grid for $20 \mathrm{~s}$. The excess solvent was wicked off. The grid was gently rinsed with 5 drops of ultrapure water and air-dried after wicking off excess solvent.

Oscillatory Shear Rheology. Oscillatory shear rheology was performed on a TA Instruments Discovery Hybrid Rheometer (DHR-2) with a $20 \mathrm{~mm}$ parallel plate geometry and a gap size of $1 \mathrm{~mm}$. Strain sweeps of hydrogel samples were conducted at a constant 
frequency of $1 \mathrm{~Hz}$. Frequency sweeps were performed at $1 \%$ strain and $25^{\circ} \mathrm{C}$. Step creep recovery experiments were performed at 5,25 , and $45^{\circ} \mathrm{C}$ at $50 \mathrm{~Pa}$ for $200 \mathrm{~s}$, followed by $0 \mathrm{~Pa}$ for $500 \mathrm{~s}$ over three steps. All experiments were conducted using the TRIOS software package from TA. The hydrogel samples were equilibrated for $15 \mathrm{~min}$ and trimmed prior to each run.

Raman Spectroscopy. Raman characterization was carried out using a LabRAM ARAMIS (Horiba Jobin Yvon) with a $633 \mathrm{~nm}$ HeNe laser as excitation source. Spectra were recorded with a confocal hole size of $200 \mu \mathrm{m}, 1800 \mathrm{~g} / \mathrm{mm}$ grating and averaged over 32 scans in LabSPEC 5 (Horiba Jobin Yvon). All Raman spectra were baseline subtracted and normalized using OriginPro 8.5.

UV-Vis Spectroscopy. UV-vis characterization was conducted on a Molecular Devices Spectra Max M2 spectrophotometer with Greiner Bio-one 96 well clear-bottom polypropylene reader plates.

Size Exclusion Chromatography (SEC). SEC was performed in $N, N$ dimethylacetamide with $50 \mathrm{mM} \mathrm{LiCl}$ at $50{ }^{\circ} \mathrm{C}$ and a flow rate of $1.0 \mathrm{~mL} / \mathrm{min}$ (Agilent isocratic pump, degasser, and autosampler; columns: Viscogel I-series $5 \mu \mathrm{m}$ guard + two ViscoGel I-series G3078 mixed bed columns, molecular weight range $0-20 \times 10^{3}$ and 0-100 $\times 10^{4} \mathrm{~g} / \mathrm{mol}$ ). Detection consisted of Wyatt Optilab T-rEX refractive index detector operating at $658 \mathrm{~nm}$. Relative molecular weights were obtained through calibration with poly(styrene) (PS) standards of molecular weights ranging from 1.3 to $327 \mathrm{kDa}$.

Cyclic Voltammetry (CV). CV measurements were performed at $20{ }^{\circ} \mathrm{C}$ using an EG\&G Princeton Applied Research Potentiostat/Galvanostat Model 263A was used to apply the voltage at a scan rate of $0.1 \mathrm{~V} / \mathrm{s}$. The analyte concentration was $10 \mathrm{mM}$ in a $0.1 \mathrm{M}$ solution 
of $\mathrm{TBABF}_{4}$ in DMF. DMF was degassed for $30 \mathrm{~min}$ under vacuum and dried over molecular sieves $(3 \AA)$ prior to use. We used a glassy carbon microelectrode as the working electrode, a platinum counter electrode, and a saturated $\mathrm{Ag} / \mathrm{AgCl}$ reference electrode. To qualitatively compare the reduction potentials measured against $\mathrm{Ag} / \mathrm{AgCl}$ with the EY redox potentials reported against saturated calomel electrode (SCE), the $\mathrm{Ag} / \mathrm{AgCl}$ potentials were converted to SCE by subtracting $0.045 \mathrm{~V} .^{3}$

Cell Viability. The gels were prepared as described under S3, using Dulbecco's Modified Eagle Medium (DMEM) with 4.5g/L glucose, L-glutamine, and sodium pyruvate supplemented with $10 \%$ FBS and $1 \%$ penicillin streptomycin instead of pure water. The cells were dyed with cell tracker green (CMFDA) and plated with either UV-cured PEGPhDL gels (Figure S20) or with the uncured hydrogel precursor solution (Figure S21). Ethidium homodimer was added to the gel, allowing living cells to fluoresce green and dead cells to fluoresce red and imaged after one hour and after six hours. To assess percent cell viability, the amount of living cells was determined based on cell fluorescence. All cells in the frame were counted, and then any cells fluorescing red were counted. The number of cells fluorescing red was subtracted from the total number of cells to determine the number of living cells. The number of living cells was then divided by the total number of cells and multiplied by 100 to determine the percent of living cells. This was repeated three times per image. 
S3. Supplementary Figures

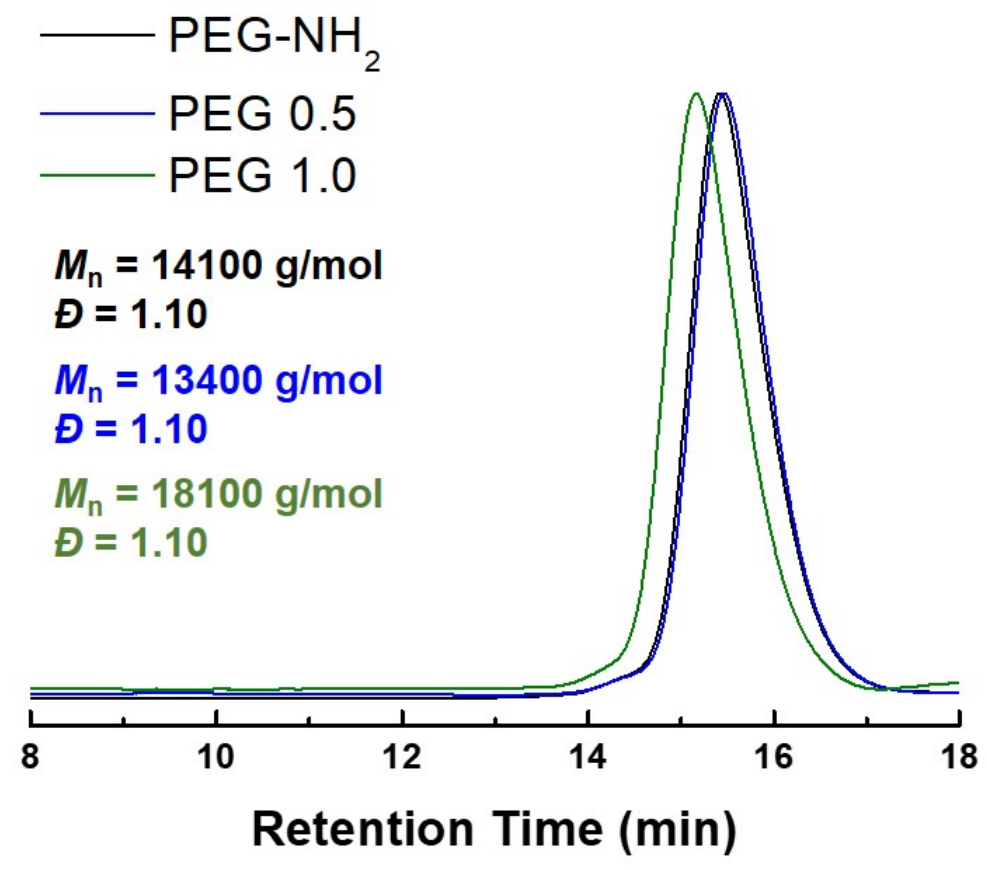

Figure S1. Overlaid SEC traces of PEG-diamine (PEG-NH $)_{2}$, amidomethylester PEG (PEG 0.5), and amidoamine PEG (PEG 1.0).<smiles>[R]N([R])CCOCC(C)OCCN([R])CCC(=O)NCCNCCC(=O)OC1(c2ccccc2)CSC1</smiles>

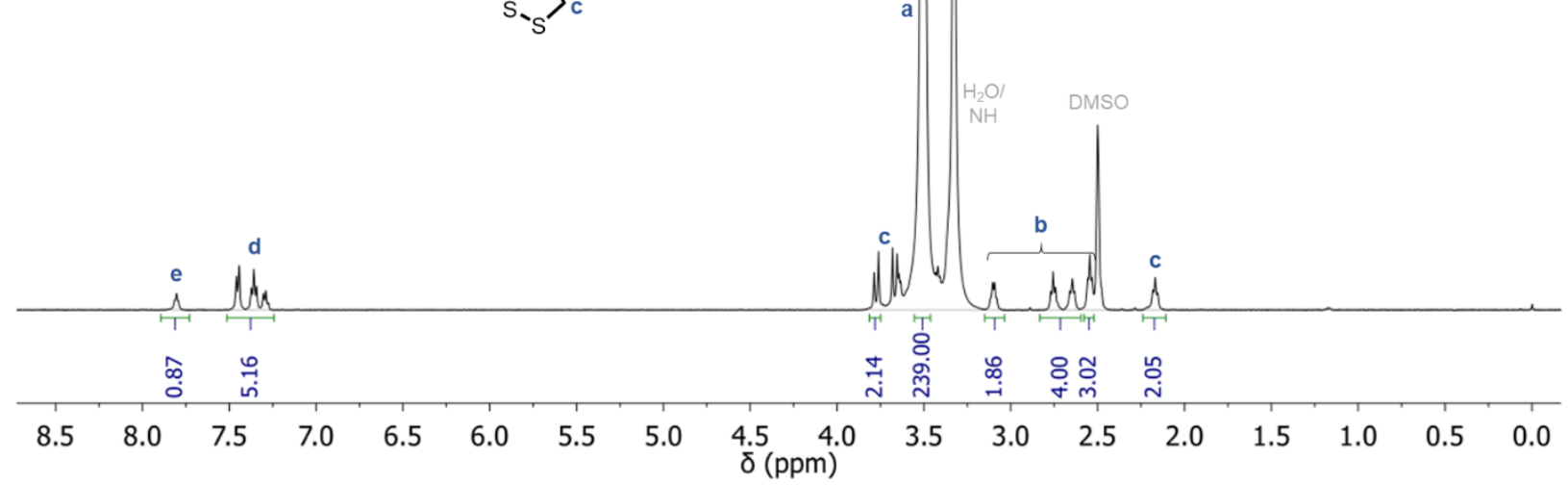

Figure S2. ${ }^{1} \mathrm{H}$ NMR spectrum of PEG-PhDL in DMSO- $d_{6}$. The PhDLA conjugation was carried out in $\mathrm{DMF} / \mathrm{MeOH}(4: 1)$ at $30^{\circ} \mathrm{C}$ and $25 \mathrm{mg} / \mathrm{mL}$ PEG 1.0 concentration. The total 1,2-dithiolane incorporation after $30 \mathrm{~h}$ reaction time is $52 \%$, as determined by the aromatic signals around $7.4 \mathrm{ppm}$ relative to the PEG backbone signal at $3.55 \mathrm{ppm}$. 


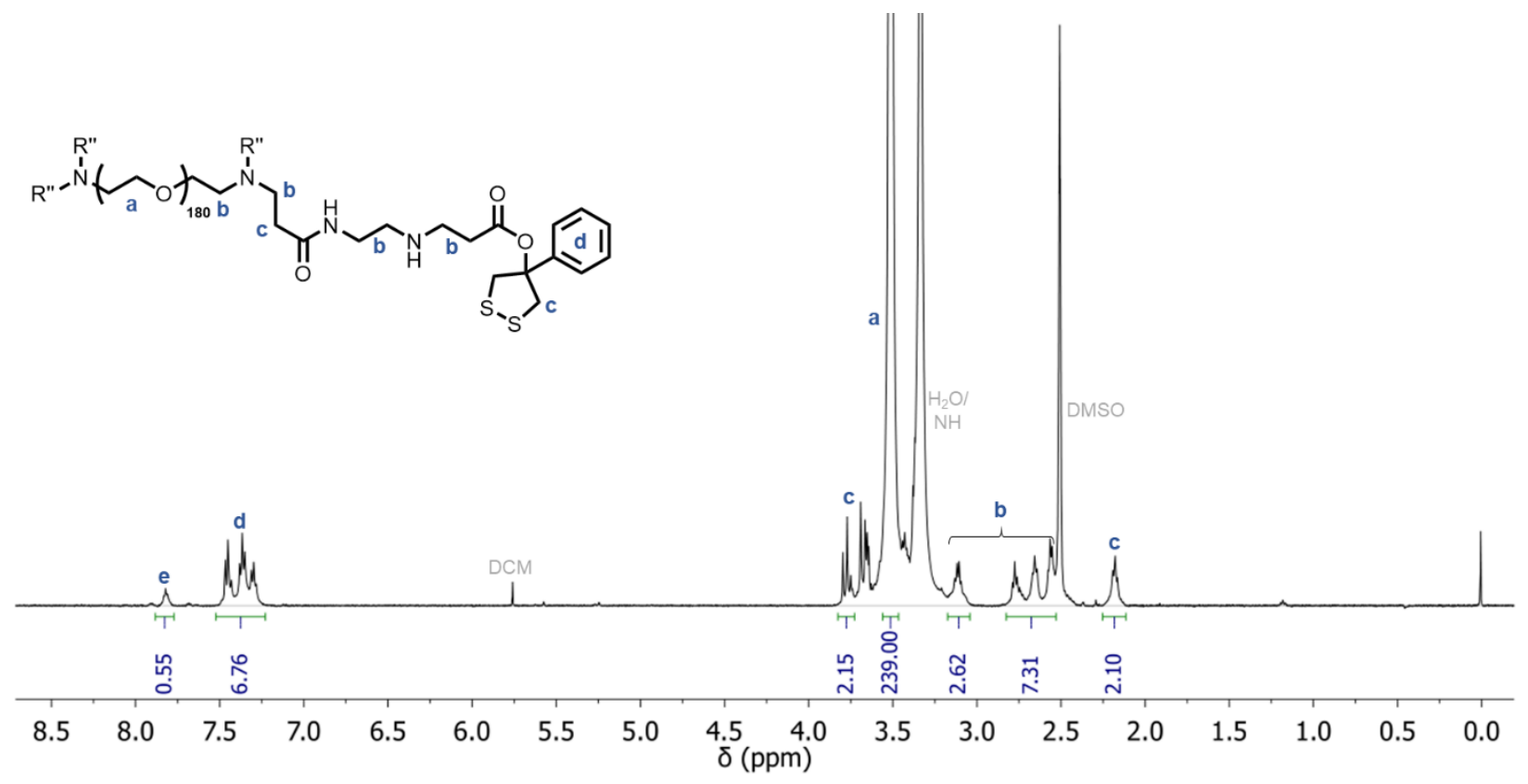

Figure S3. ${ }^{1} \mathrm{H}$ NMR spectrum of PEG-PhDL in DMSO- $d_{6}$. The PhDLA conjugation was carried out in DMF at $30{ }^{\circ} \mathrm{C}$ and $125 \mathrm{mg} / \mathrm{mL}$ PEG 1.0 concentration. The total 1,2-dithiolane incorporation after $7.5 \mathrm{~h}$ reaction time is $68 \%$, as determined by the aromatic signals around 7.4 ppm relative to the PEG backbone signal at $3.55 \mathrm{ppm}$.
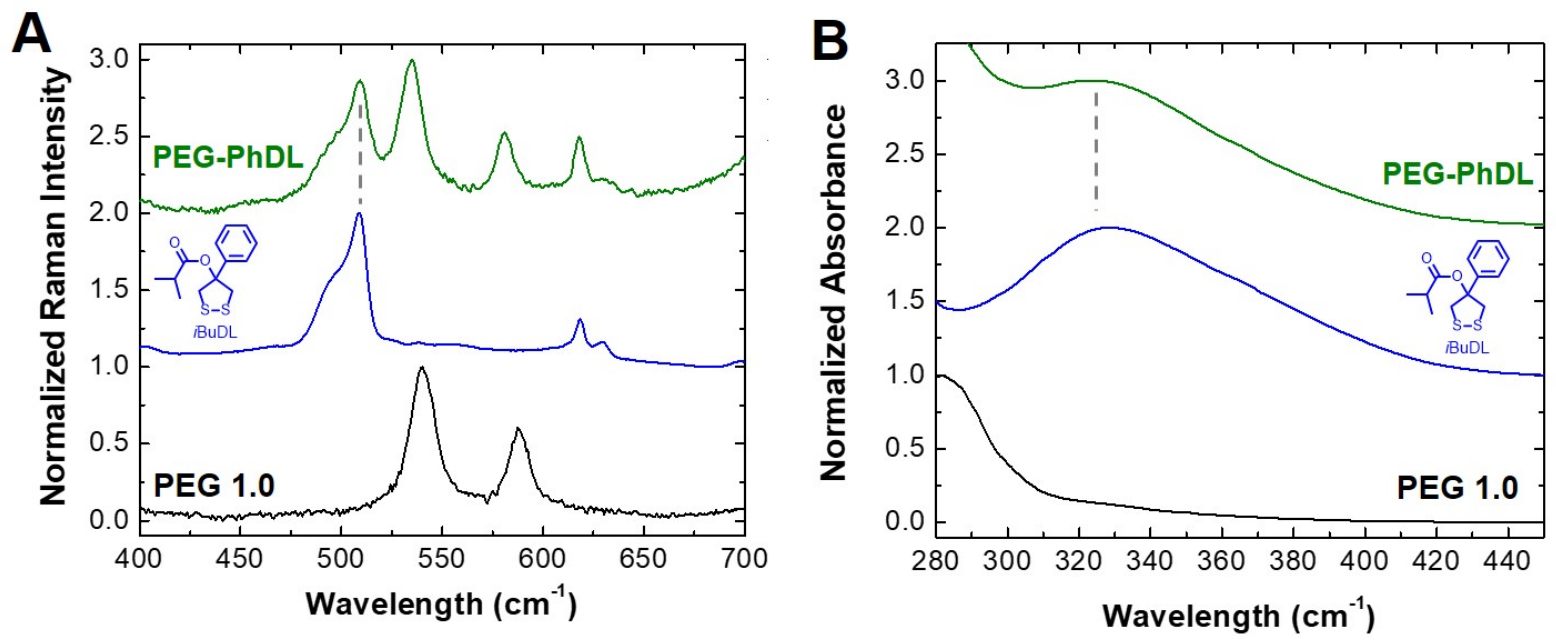

Figure S4. Spectroscopic evidence for 1,2-dithiolane incorporation by comparing unfunctionalized PEG 1.0, model compound iBuDL, and 1,2-dithiolane-functionalized PEG-PhDL. (A) The stacked Raman spectra show a distinct signal around $502 \mathrm{~cm}^{-1}$ for PEG-PhDL, which is characteristic for the disulfide bond in 1,2dithiolanes. (B) Stacked UV-vis spectra show the appearance of the 1,2-dithiolane absorbance around 335 $\mathrm{nm}$ for PEG-PhDL. 


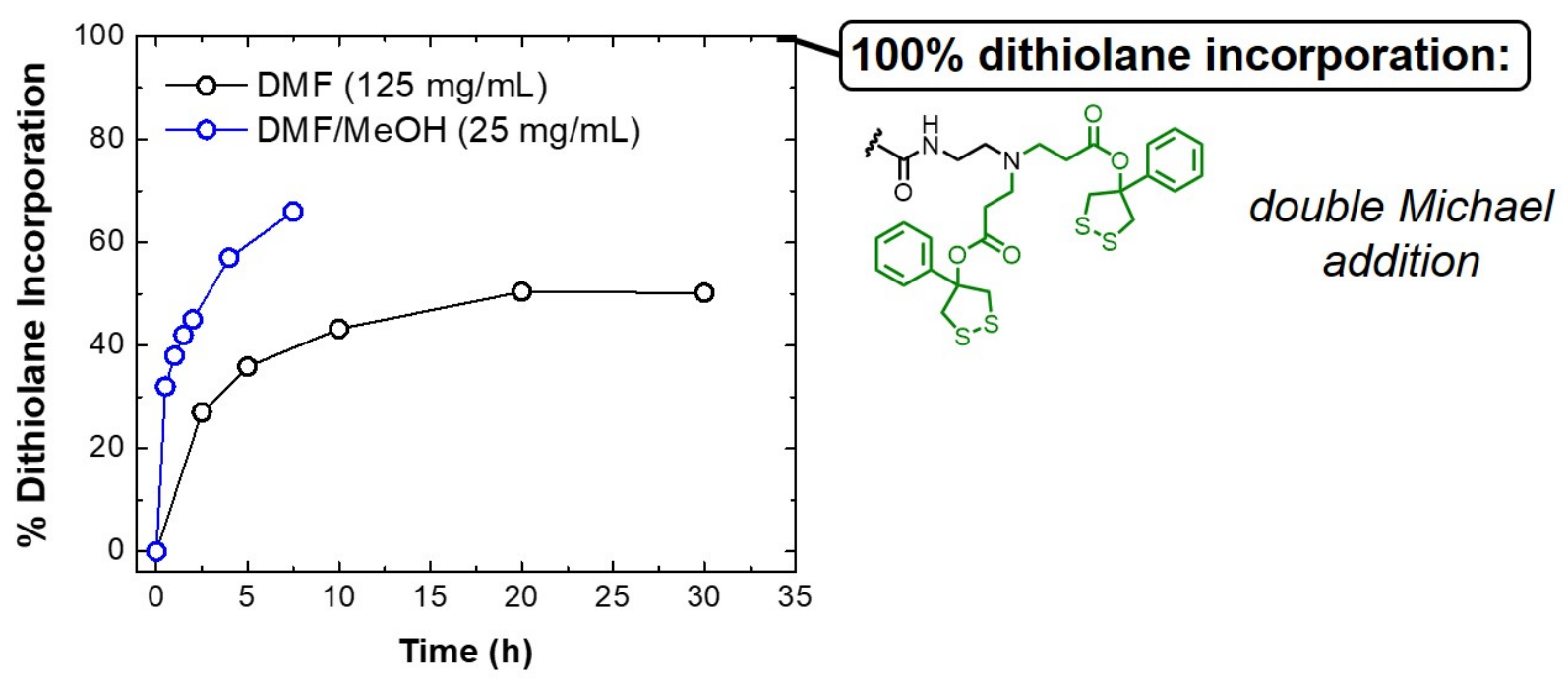

Figure S5. Kinetic profile of the PhDLA conjugation with PEG 1.0 at $30{ }^{\circ} \mathrm{C}$. In DMF at high polymer concentration, $68 \%$ 1,2-dithiolane incorporation is achieved after $7.5 \mathrm{~h}$. In $\mathrm{DMF} / \mathrm{MeOH}(4: 1)$, the incorporation stalls at $50 \%$, even after elongated reaction times.

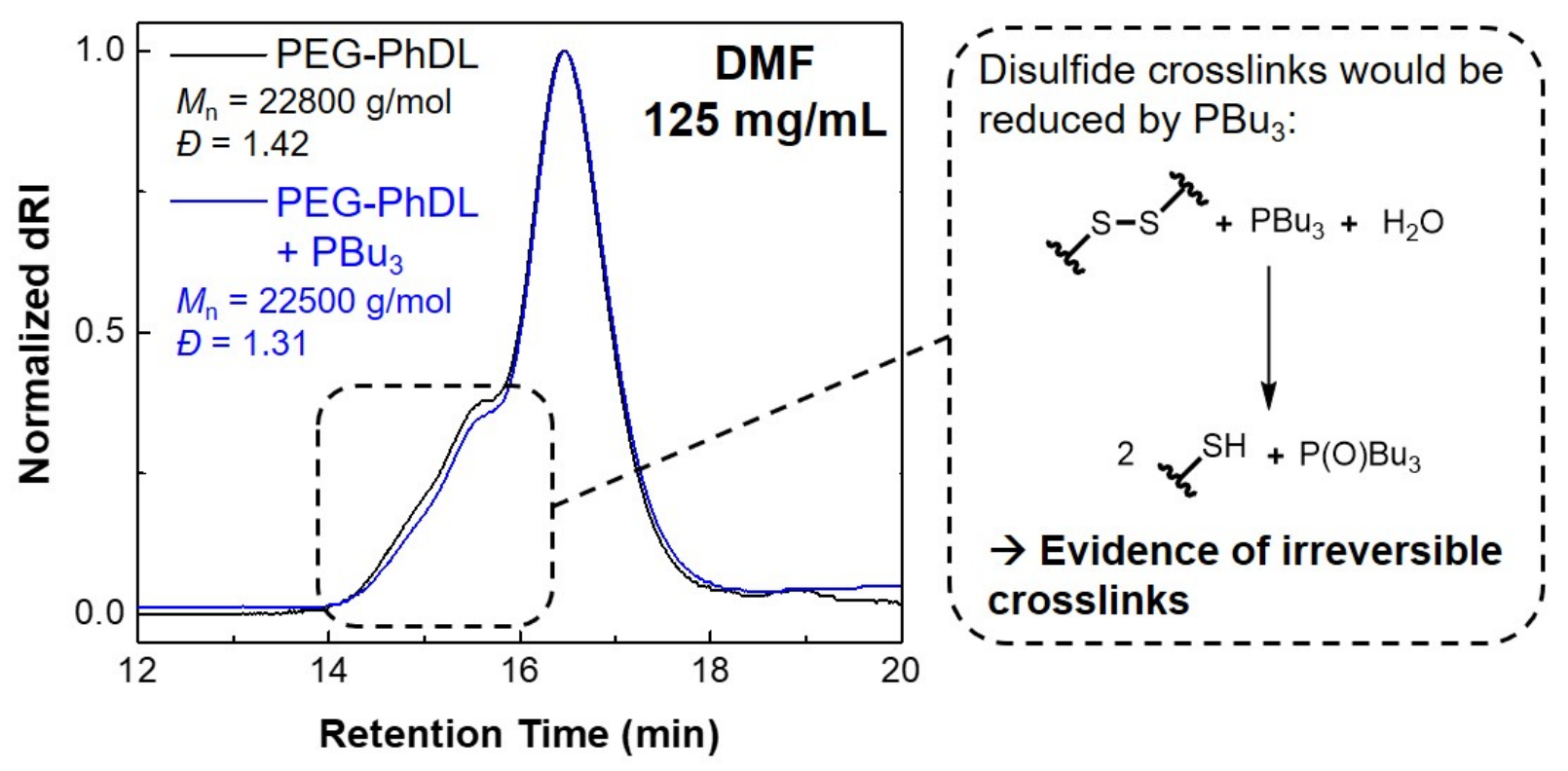

Figure S6. Overlaid size-exclusion chromatograms of PEG-PhDL before (black) and after (blue) the addition of the disulfide reducing agent $\mathrm{PBu}_{3}$. The minor change of the trace suggests that the highmolecular weight species are predominantly formed from irreversible polymer chain coupling and not interchain disulfide formation. The mechanism for disulfide reduction is adapted from Humphrey et al. ${ }^{4}$ 

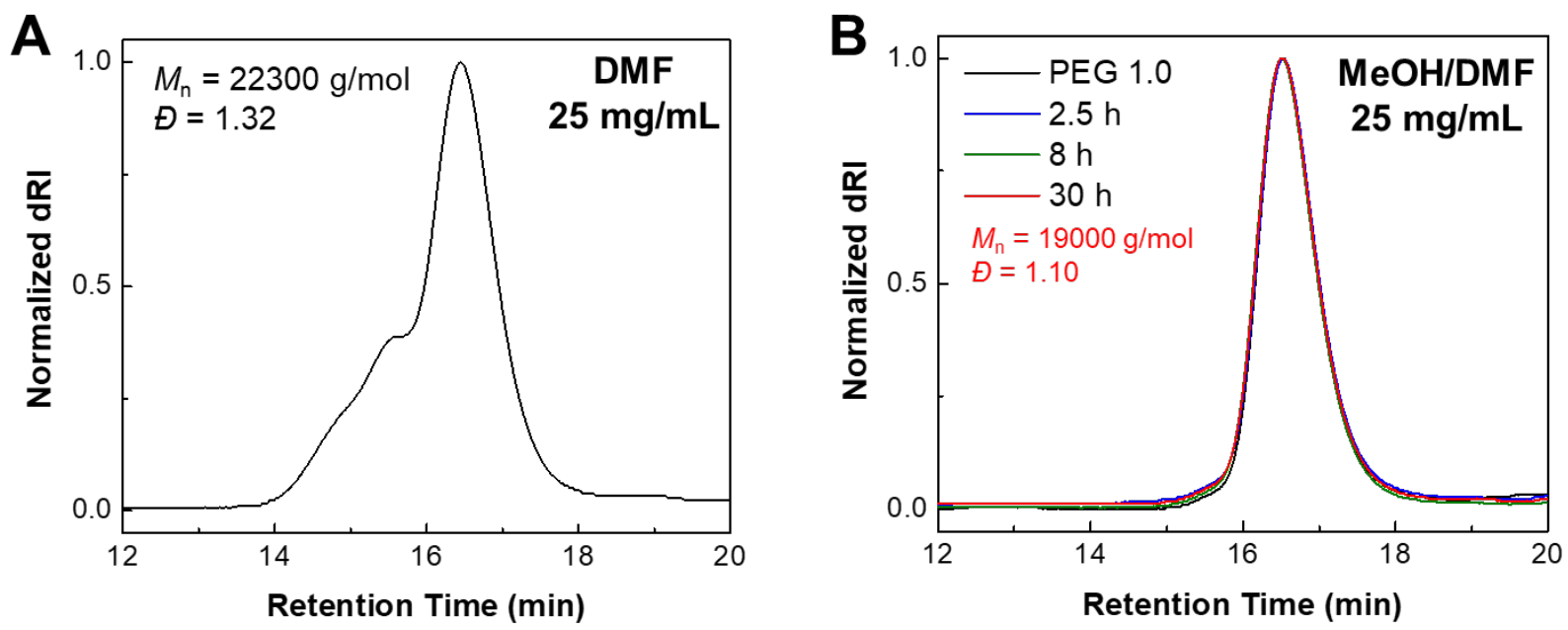

Figure S7. Comparison of PEG-PhDL SEC traces showing the solvent dependence on the formation of high molecular weight species. (A) Size-exclusion chromatogram of PEG-PhDL synthesized in DMF at 25 $\mathrm{mg} / \mathrm{mL}$ PEG 1.0 concentration. The molecular weight and the molecular weight distributions are similar to PEG-PhDL formed at $125 \mathrm{mg} / \mathrm{mL}$ (Figures 2 and S6). (B) No high molecular weight shoulder was observed if the reaction is carried out in $\mathrm{DMF} / \mathrm{MeOH}(4: 1)$ at the same polymer concentration. These results suggest the formation of the high molecular weight shoulder is mostly dictated by the solvent composition.

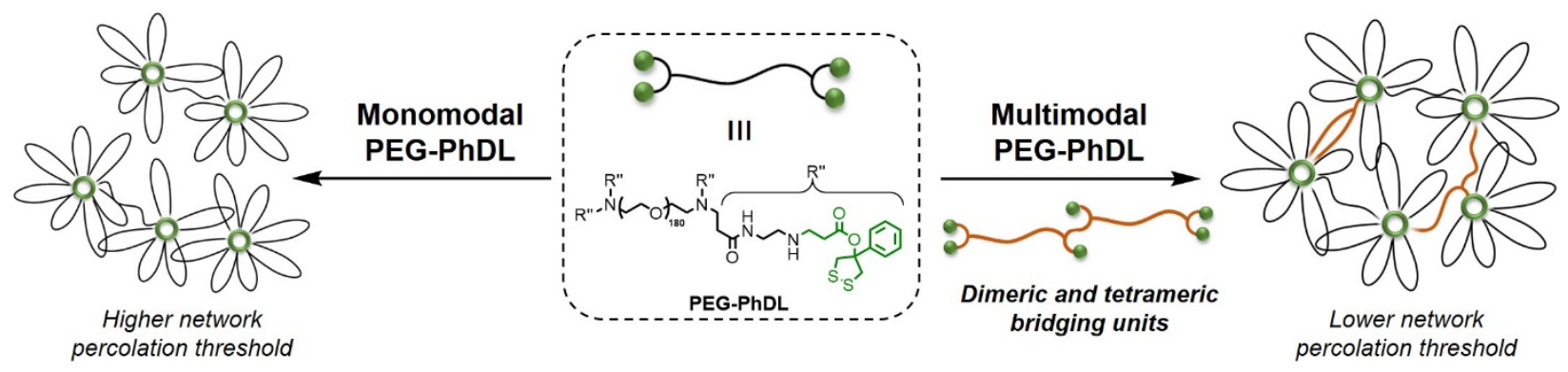

Figure S8. Schematic depiction of dimeric and tetrameric PEG-PhDL acting as more efficient bridging agents between 1,2-dithiolane aggregates, resulting in network formation at lower polymer concentrations.
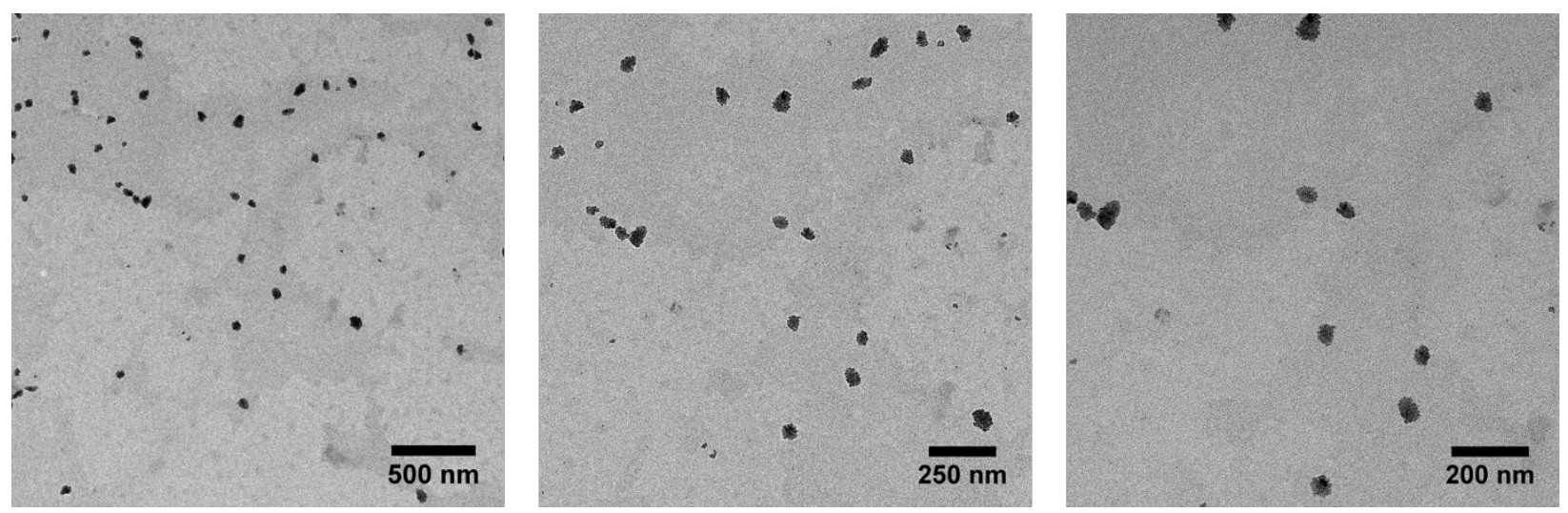

Figure S9. Transmission electron microscope images of PEG-PhDL at $1 \mathrm{wt} \%$ in water. 


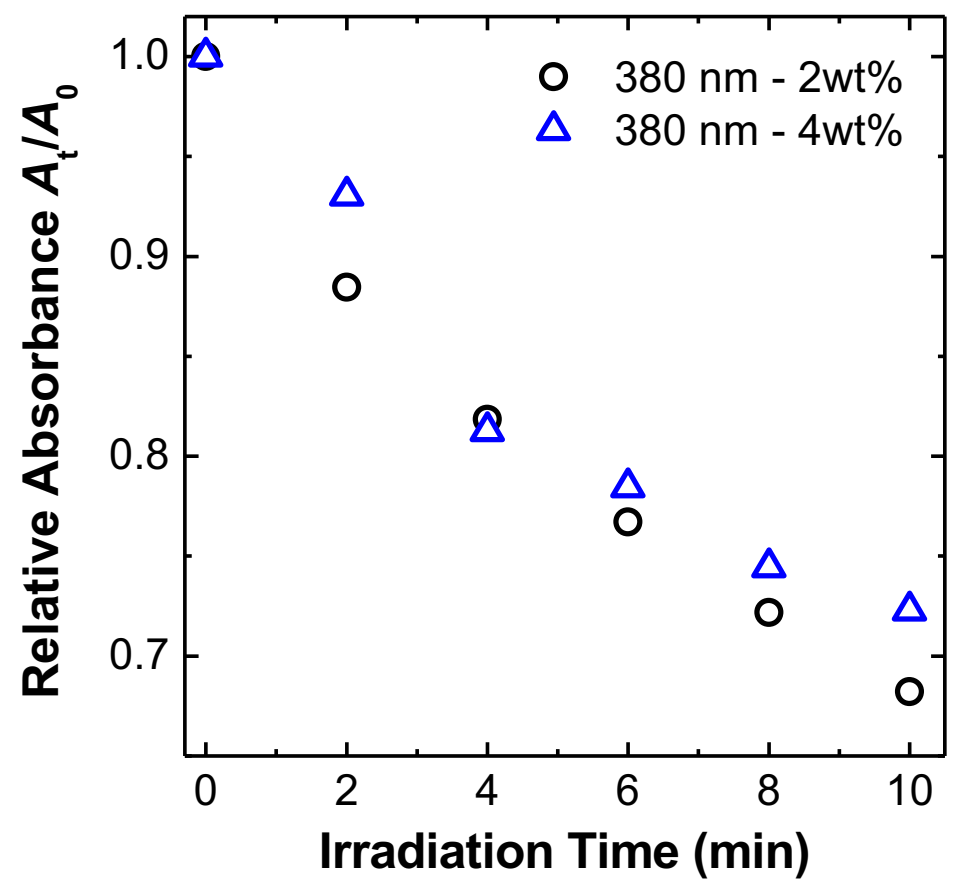

Figure S10. Investigation of PEG-PhDL photolysis in water upon UV irradiation $\left(\lambda_{\max }=365 \mathrm{~nm}\right)$. The decrease of the relative 1,2-dithiolane absorbance $\left(A_{t} / A_{0}\right)$ determined at $380 \mathrm{~nm}$ after different irradiation times for 2 and $4 \mathrm{wt} \%$ solutions of PEG-PhDL was found to be similar for both concentrations.

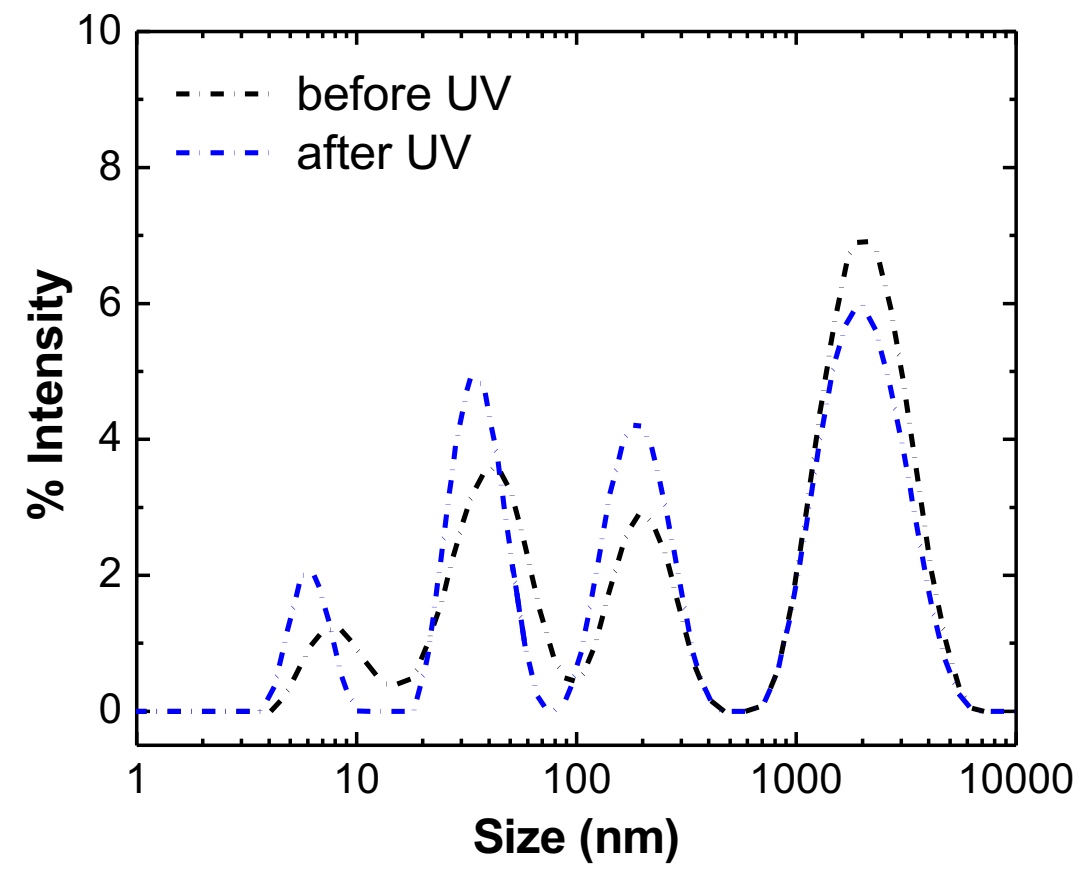

Figure S11. Dynamic light scattering traces of PEG-PhDL in water at $2 \mathrm{wt} \%$ before and after UV irradiation. 

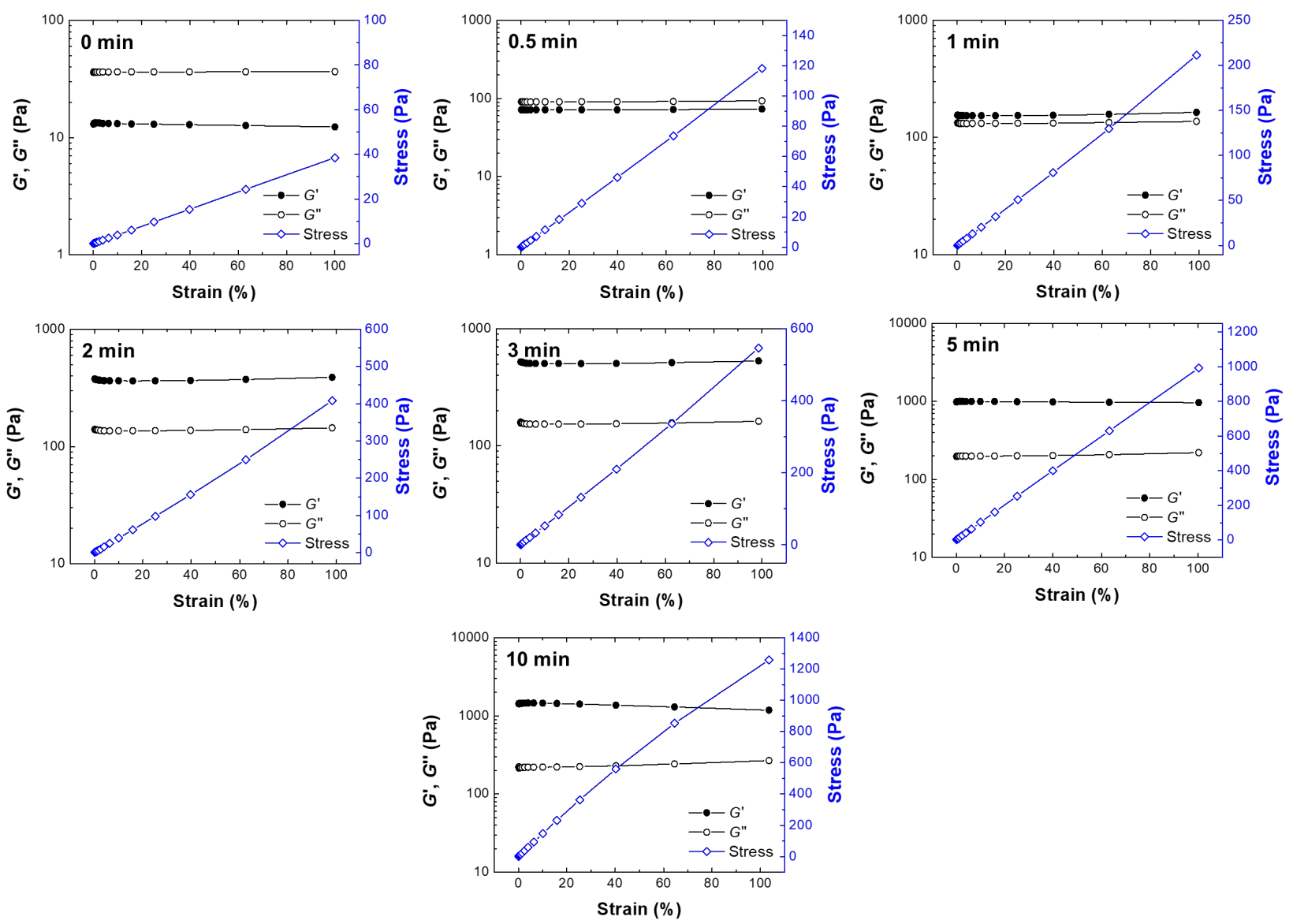

Figure S12. Strain sweeps at $1 \mathrm{~Hz}$ of PEG-PhDL hydrogels formed after different irradiation times. The irradiation time is indicated in the upper left corner of the graphs. 


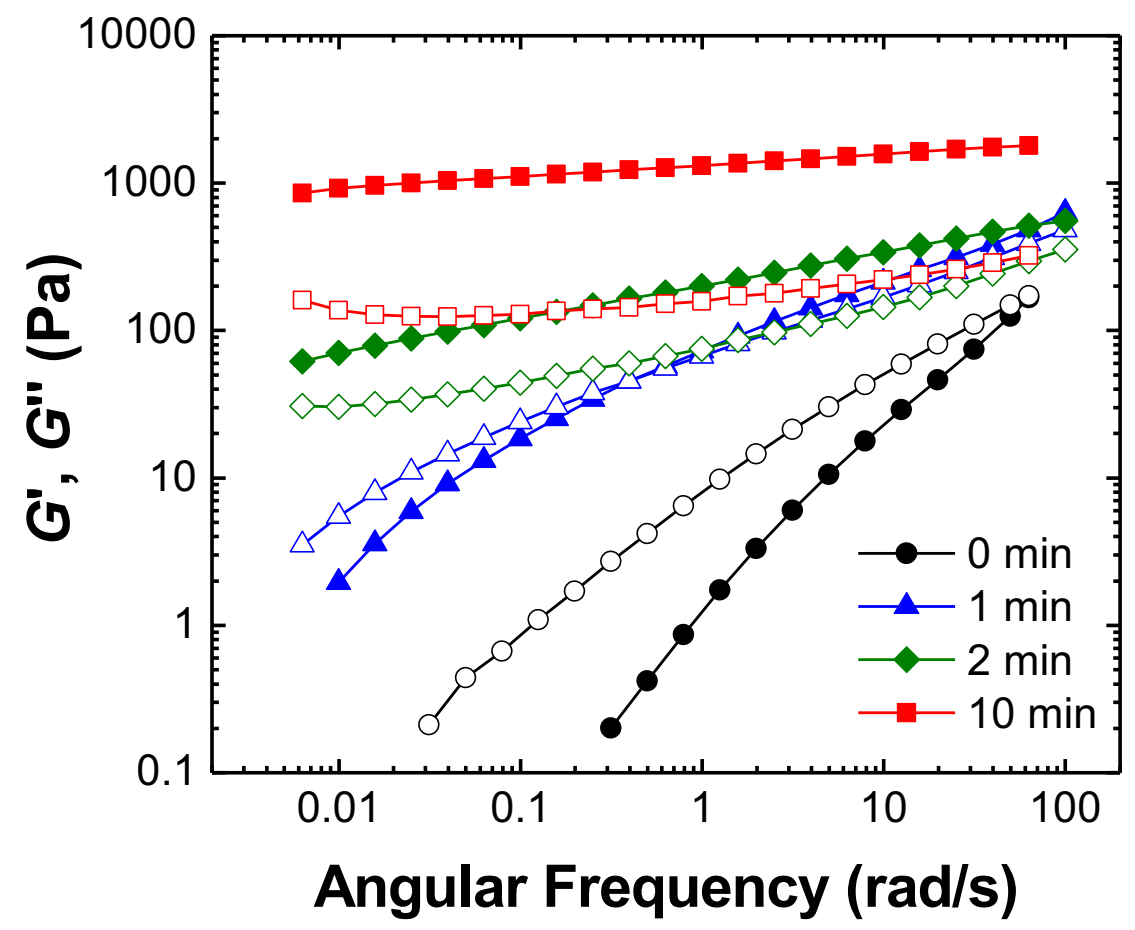

Figure S13. Overlaid frequency sweeps of PEG-PhDL hydrogels after varying irradiation times.

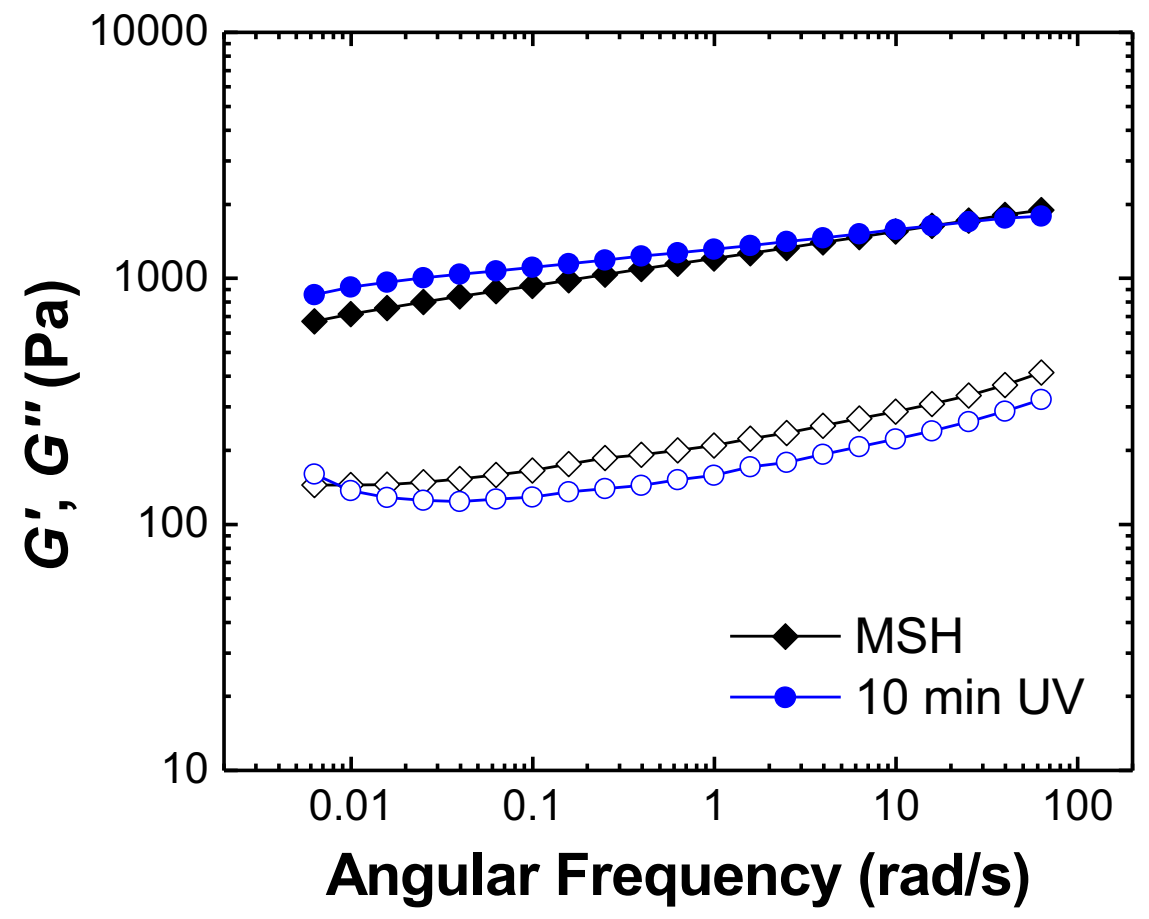

Figure S14. Overlaid frequency sweeps of PEG-PhDL hydrogels crosslinked via thiol-induced ringopening using 2-mercaptoethanol (MSH; black) or UV irradiation for $10 \mathrm{~min}$ (blue). 


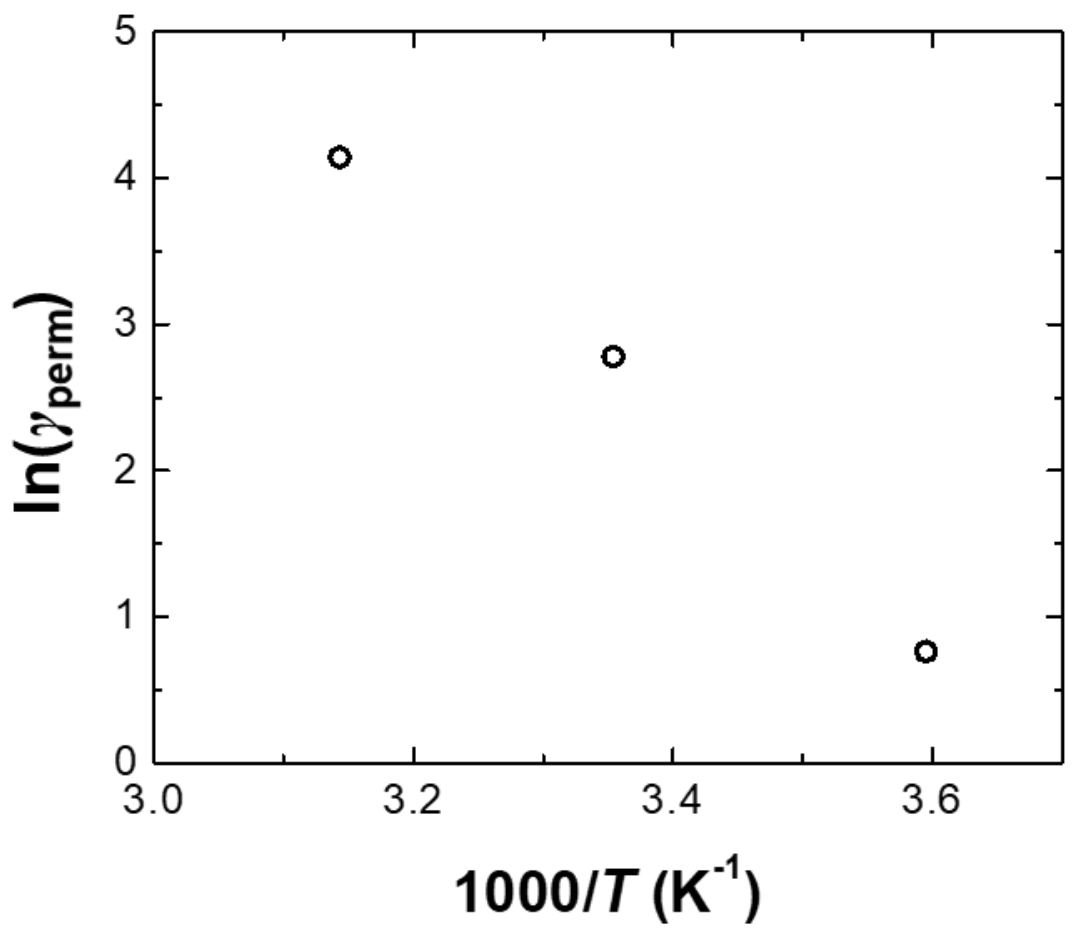

Figure S15. Temperature dependence of the permanent deformation ( $/$ perm) plotted in an Arrhenius-type fashion.

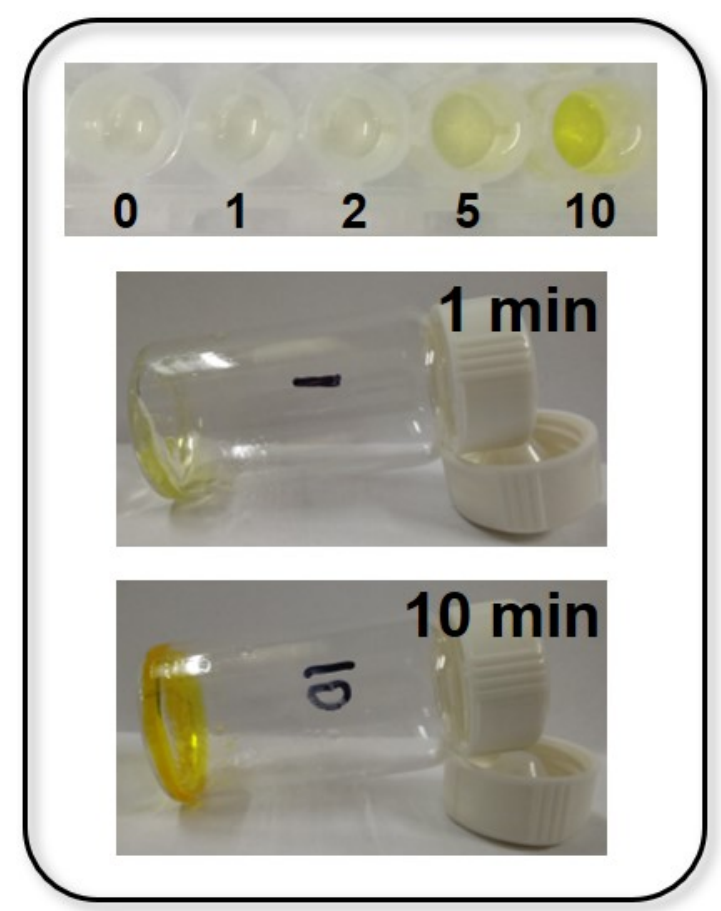

Figure S16. Photographs of the Ellman's supernatant after incubating with PEG-PhDL hydrogels irradiated for $0,1,2,5$, and 10 min (top). Photographs of the gels stained by Ellman's reagent after irradiating for 1 and 10 min (bottom). 


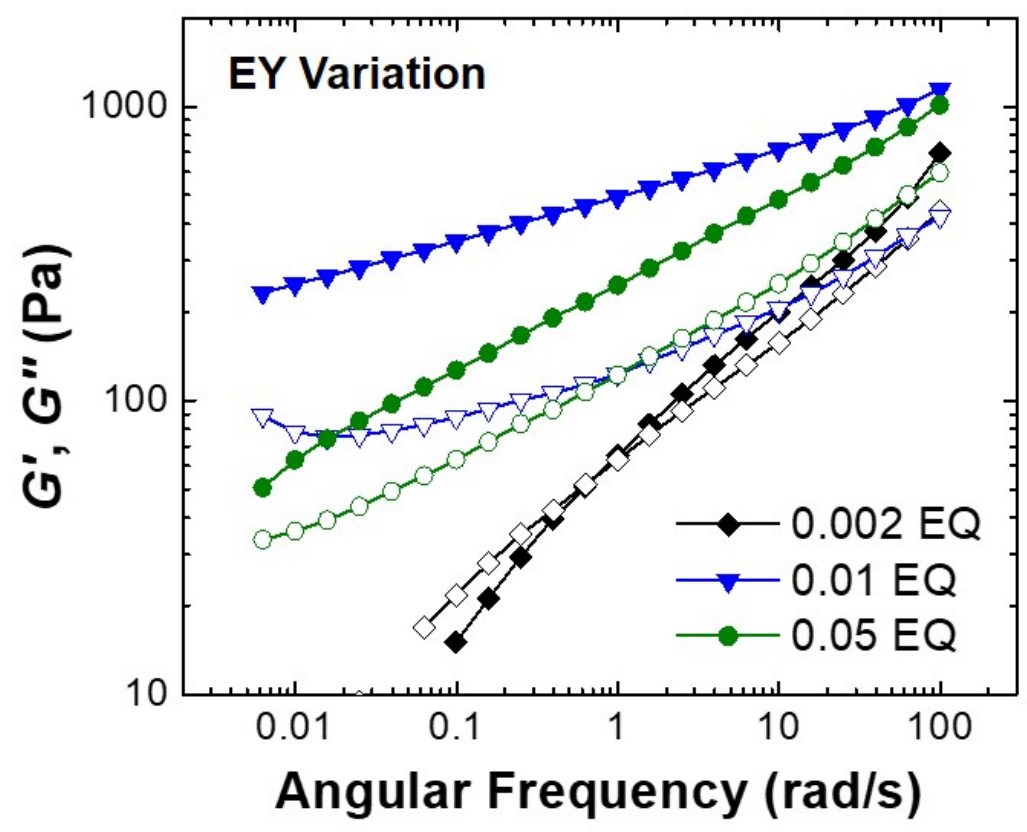

Figure S17. Overlaid frequency sweeps of PEG-PhDL hydrogels cured with varying molar equivalents (EQ) of eosin y (EY).

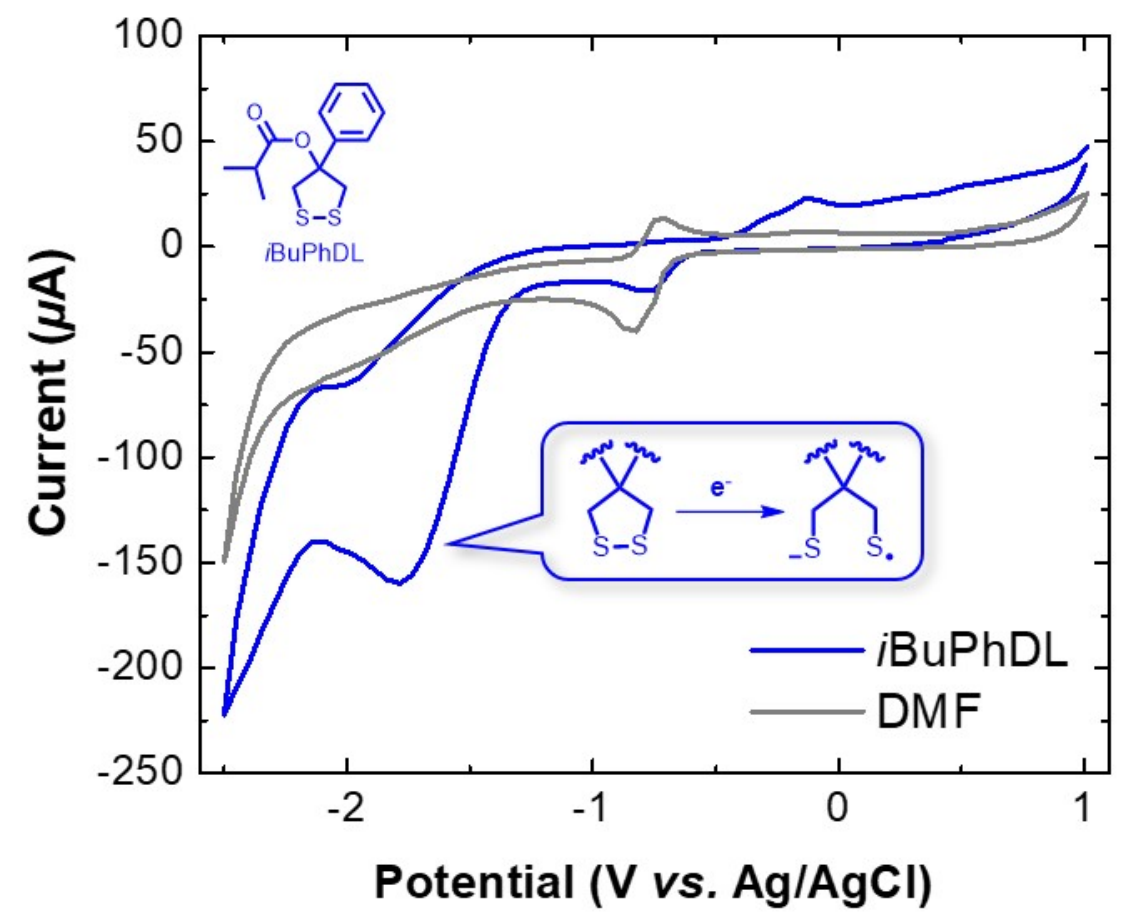

Figure S18. Cyclic voltammogram of $\mathrm{BuPhDL}$ (blue), the small molecule model compound for PEG-PhDL. The main reduction peak for the 1,2-dithiolane is observed at $-1.78 \mathrm{~V}$ against $\mathrm{Ag} / \mathrm{AgCl}$, which corresponds to -1.83 against SCE. The peak around $-0.82 \mathrm{~V}$ stems from the reduction of residual oxygen in DMF (grey). ${ }^{5}$ 


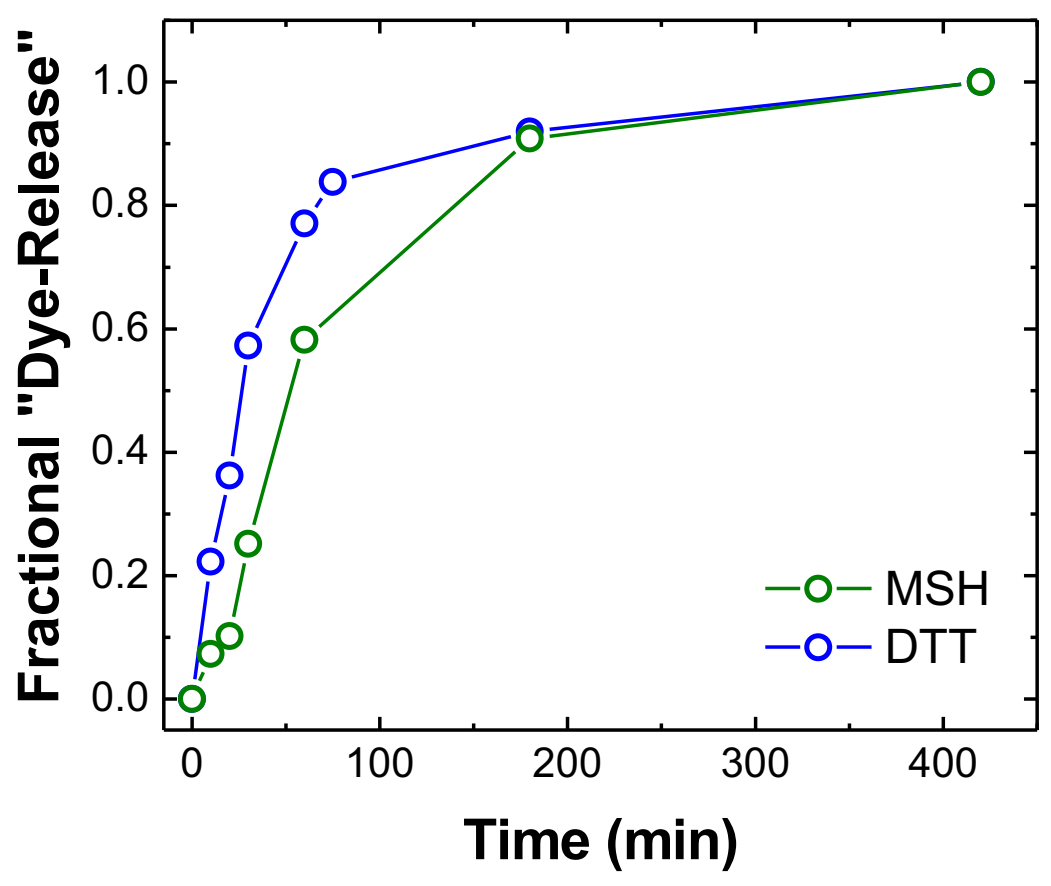

Figure S19. Expansion of the dye release profile for the PEG-PhDL gels under fast thiol-disulfide exchange conditions with excess 2-mercaptoethanol (MSH) and dithiothreitol (DTT).

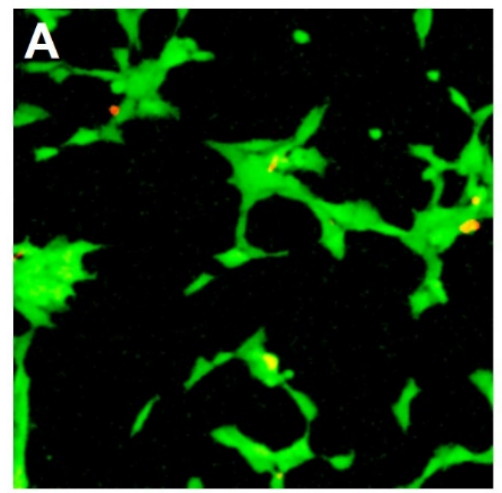

Cells plated with cured PEG-PhDL gel, imaged after $1 \mathrm{~h}$

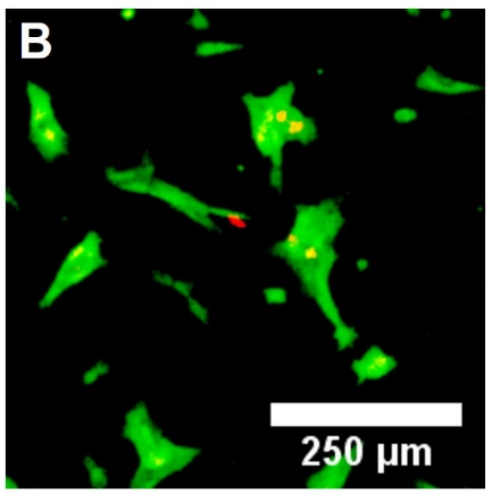

Cells plated with cured PEG-PhDL gel, imaged after $6 \mathrm{~h}$

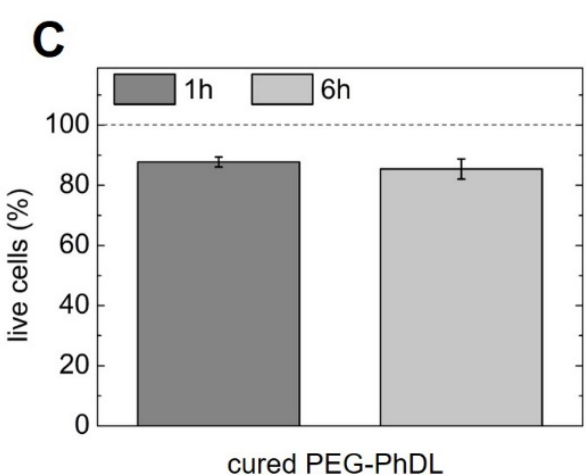

cured PEG-PhDL

Figure S20. Confocal microscopy images of NIH-3t3 cells plated with UV-cured PEG-PhDL hydrogels. Live cells are shown in green, and dead cells appear red. (A) Cells were plated with a PEG-PhDL gel that has been cured for 10 min with UV light. (B) Image of the cells depitcted in (A) after $6 \mathrm{~h}$ incubation. (C) Cell viability under conditions of $(A)$ and $(B)$. 


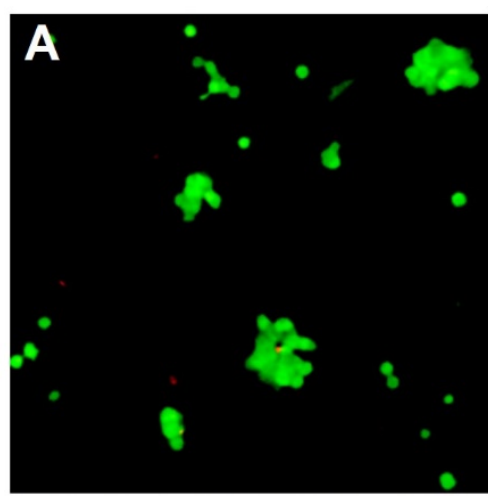

Cells plated with PEG-PhDL solution, imaged after $1 \mathrm{~h}$
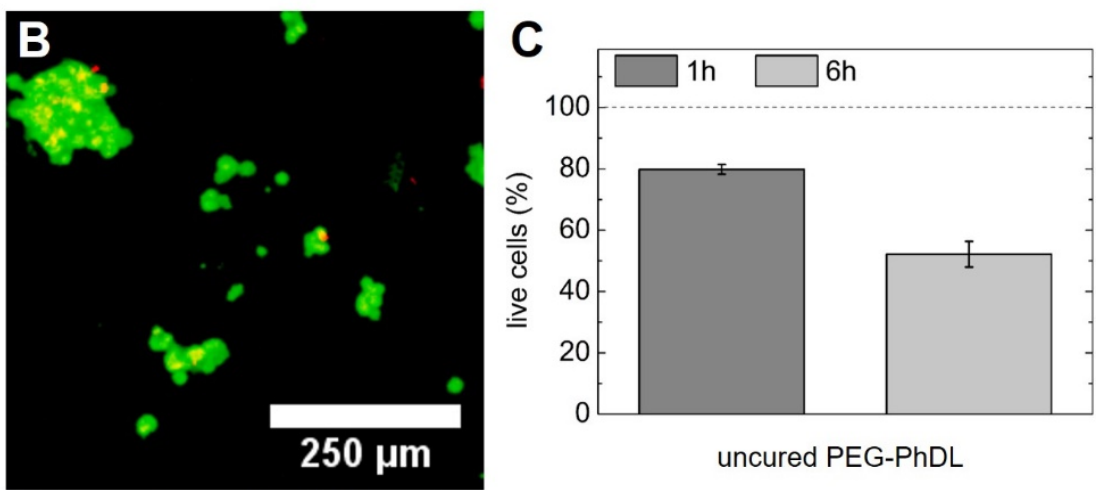

Cells plated with PEG-PhDL solution, imaged after $6 \mathrm{~h}$

Figure S21. (A) Image of cells plated with PEG-PhDL precursor after $1 \mathrm{~h}$ of incubation. (B) Image of the cells shown in (A) after $6 \mathrm{~h}$ incubation. (C) Cell viability under conditions of $(A)$ and $(B)$. These results show that prolonged exposure of cells to uncured PEG-PhDL polymer can limit cell viability, potentially due to interactions of the 1,2-dithiolane end-groups with thiols on the cell surface. ${ }^{6}$
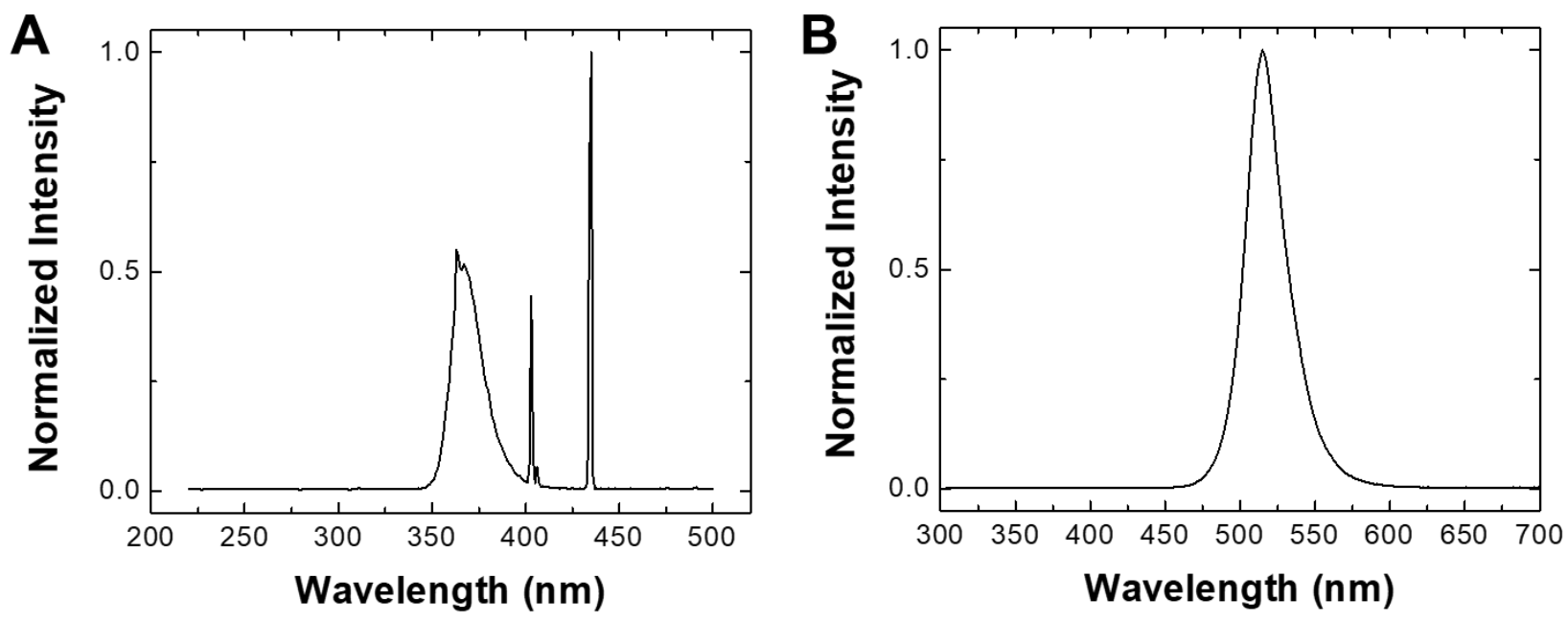

Figure S22. Lamp emission spectra for the (A) UV light and (B) green light.

\section{S4. Calculation of $E_{\mathrm{s}}$ and $E_{\mathrm{d}}$}

Following the notation of Macosko ${ }^{7}$ and Goodwin, ${ }^{8}$ integration of the stress over one cyclic period of strain, the average energy stored $\left(E_{\mathrm{s}}\right)$ and dissipated $\left(E_{\mathrm{d}}\right)$ per unit volume can be calculated with equations 1 and 2 :

$E_{S}=\frac{G r(\omega) \gamma_{0}^{2}}{4}$ 
$E_{d}=\pi G^{\prime \prime}(\omega) \gamma_{0}^{2}$

Where $\gamma_{0}$ is the maximum strain, $\mathrm{G}^{\prime}$ is the storage modulus, $\mathrm{G}^{\prime \prime}$ is the loss modulus and $\omega$ corresponds to the angular frequency. Using equation 3 , the ratio of $E_{d}$ to $E_{\mathrm{s}}$ can be estimated:

$\frac{E_{d}}{E_{S}}=\frac{4 \pi G \prime \prime(\omega)}{G \prime(\omega)}$

With $G^{\prime}=857 \mathrm{~Pa}$ and $G^{\prime \prime}=160 \mathrm{~Pa}$ at $\omega=0.006 \mathrm{rad} / \mathrm{s}$ and $E_{\mathrm{s}}=1-E_{\mathrm{d}}$, we obtain $E_{\mathrm{d}}=$ 0.70 after solving equation 4 for $E_{\mathrm{d}}$.

$\frac{E_{d}}{\left(1-E_{d}\right)}=2.35$

\section{S5. Procedures}

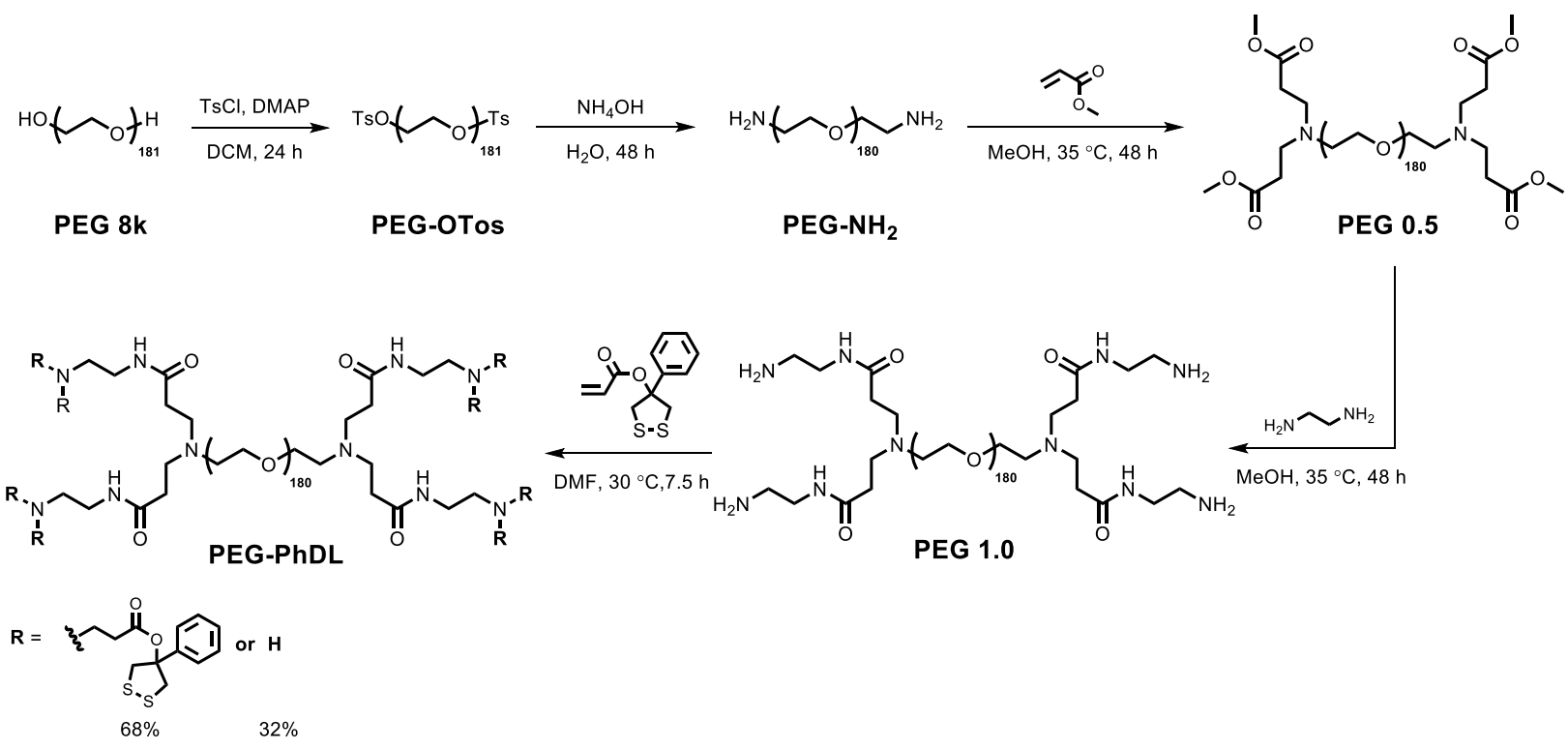

Figure S23. Synthesis of PEG-PhDL.

Synthesis of PEG-ditosylate (PEG-OTos)

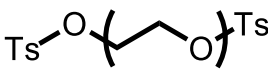

181

PEG-diol (nominal molecular weight $=8000 \mathrm{~g} / \mathrm{mol}, M_{\mathrm{n}, \mathrm{SEC}, \mathrm{PS}}=15000 \mathrm{~g} / \mathrm{mol}, 32.1 \mathrm{~g}, 4.01$ 
mmol) was dissolved in of dry DCM $(150 \mathrm{~mL})$ and dried over MS $4 \AA$ overnight. This solution was then transferred via cannula to a solution of $p$-tosyl chloride ( $3.06 \mathrm{~g}, 16.0$ mmol), TEA (1.62 g, $16.0 \mathrm{mmol})$ and DMAP $(0.24 \mathrm{~g}, 1.9 \mathrm{mmol})$ in dry DCM $(20 \mathrm{~mL})$. After $24 \mathrm{~h}$, the product was precipitated three times into cold $\mathrm{Et}_{2} \mathrm{O}$.

${ }^{1}{ }^{H}$ NMR $\left(500 \mathrm{MHz}, \mathrm{DMSO}-\mathrm{d}_{6}\right) \delta 7.78(\mathrm{~d}, 4 \mathrm{H}), 7.48(\mathrm{~d}, 4 \mathrm{H}), 4.11(\mathrm{~m}, 4 \mathrm{H}), 3.51$ (br, PEG backbone), $2.41(\mathrm{~s}, 6 \mathrm{H})$.

Synthesis of PEG-diamine (PEG-NH2)<smiles>NCCCOCCN</smiles>

PEG-OTos (18.5 g, $2.31 \mathrm{mmol}$ ) was dissolved in aqueous $\mathrm{NH}_{4} \mathrm{OH}(200 \mathrm{~mL}, 30 \mathrm{wt} \%)$, and the solution was stirred for $48 \mathrm{~h}$. The aqueous phase was extracted twice with DCM, and the product was precipitated three times into cold $\mathrm{Et}_{2} \mathrm{O}$.

${ }^{1} \mathrm{H}$ NMR (500 MHz, DMSO- $\left.d_{6}\right) \delta 3.51$ (br, PEG backbone), 2.65 (t, 4H).

$M_{\mathrm{n}}=14100 \mathrm{~g} / \mathrm{mol}$ (Figure S1)

$\Xi=1.10$

\section{Synthesis of PEG 0.5}

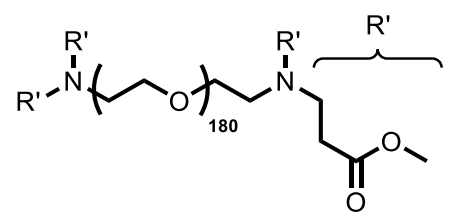

PEG-NH $\mathrm{NH}_{2}(12.0 \mathrm{~g}, 1.50 \mathrm{mmol})$ was dissolved in $60 \mathrm{~mL} \mathrm{MeOH}$, methyl acrylate $(27.2 \mathrm{~mL}$, $300 \mathrm{mmol}$ ) was added and the solution was stirred at $35{ }^{\circ} \mathrm{C}$ for $48 \mathrm{~h}$. The polymer was precipitated twice into cold $\mathrm{Et}_{2} \mathrm{O}$.

${ }^{1} \mathrm{H}$ NMR (500 MHz, DMSO- $\left.d_{6}\right) \delta 3.57$ (s, 3H), $\delta 3.51$ (br, PEG backbone), $2.70(\mathrm{t}, 2 \mathrm{H})$, 
$2.56(\mathrm{t}, 1 \mathrm{H}), 2.39(\mathrm{t}, 2 \mathrm{H})$.

$M_{\mathrm{n}}=13400 \mathrm{~g} / \mathrm{mol}$ (Figure S1)

$\Xi=1.10$

\section{Synthesis of PEG 1.0}

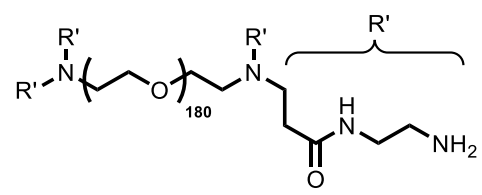

PEG $0.5(11.6 \mathrm{~g}, 1.45 \mathrm{mmol})$ was dissolved in $60 \mathrm{~mL} \mathrm{MeOH}$, ethylene diamine $(77.50 \mathrm{~mL}$, $1160 \mathrm{mmol}$ ) was added and the solution was stirred at $35^{\circ} \mathrm{C}$ for $48 \mathrm{~h}$. The polymer was precipitated twice into cold $\mathrm{Et}_{2} \mathrm{O}$.

${ }^{1} \mathrm{H}$ NMR (500 MHz, DMSO-d $)$ $) 3.51$ (br, PEG backbone), $3.22\left(\mathrm{br}, \mathrm{NH}_{2} / \mathrm{H}_{2} \mathrm{O}\right), 3.04(\mathrm{br}$, 2H), $2.66(\mathrm{t}, 4 \mathrm{H}), 2.55(\mathrm{~m}, 1 \mathrm{H}), 2.19(\mathrm{br}, 2 \mathrm{H})$.

$M_{\mathrm{n}}=18100 \mathrm{~g} / \mathrm{mol}$ (Figure S1)

$\bigoplus=1.10$

Synthesis of PEG-PhDL in DMF at $135 \mathrm{mg} / \mathrm{mL}$

PEG $1.0(2.00 \mathrm{~g}, 0.240 \mathrm{mmol}$ assuming a theoretical molecular weight of $8500 \mathrm{~g} / \mathrm{mol})$ was combined with PhDLA (0.71 g, $2.8 \mathrm{mmol})$ in DMF (15 mL) under Ar and stirred at 30 ${ }^{\circ} \mathrm{C}$. Aliquots were withdrawn after regular time intervals, precipitated into cold $\mathrm{Et}_{2} \mathrm{O}$ and analyzed by SEC and ${ }^{1} \mathrm{H}$ NMR. The 1,2-dithiolane incorporation was estimated by comparing the area of the aromatic proton signals at $7.45 \mathrm{ppm}$ with the PEG backbone. After $7.5 \mathrm{~h}$ at $30{ }^{\circ} \mathrm{C}, 68 \%$ of the maximum theoretical 1,2-dithiolane incorporation were reached and the polymer was precipitated into cold $\mathrm{Et}_{2} \mathrm{O}$ and cold hexanes. Successful conjugation of PhDLA to the polymeric substrate was confirmed by ${ }^{1} \mathrm{H}$ NMR (Figure S3), 
UV-vis and Raman spectroscopy (Figure S4).

$M_{\mathrm{n}}=22200 \mathrm{~g} / \mathrm{mol}$ (Figure 2C)

$\Xi=1.40$

Synthesis of 1,3-dichloro-2-phenylpropan-2-ol<smiles>OC(CCl)(CCl)c1ccccc1</smiles>

Magnesium turnings $(2.11 \mathrm{~g}, 86.7 \mathrm{mmol})$ were placed into a flame-dried three-neck round bottom flask, equipped with an addition funnel and a reflux condenser under $\mathrm{Ar}$ atmosphere. Dry Et $2 \mathrm{O}(30 \mathrm{~mL})$ was added, followed by a third of the total bromobenzene $(13.61 \mathrm{~g}, 86.67 \mathrm{mmol})$ solution in dry $\mathrm{Et}_{2} \mathrm{O}(50 \mathrm{~mL})$. The reaction mixture was gently heated until the Grignard reaction started, upon which the remaining bromobenzene solution was added dropwise, maintaining a smooth reflux of the reaction mixture. After complete addition, the mixture was refluxed for $1 \mathrm{~h}$ and cooled to $-15{ }^{\circ} \mathrm{C}$ in a $\mathrm{NaCl} /$ ice bath. 1,3-Dichloroacetone $(10.00 \mathrm{~g}, 78.76 \mathrm{mmol})$ in $\mathrm{dry}^{\mathrm{Et}} \mathrm{t}_{2} \mathrm{O}(100 \mathrm{~mL})$ was added dropwise. Upon complete addition, the mixture warmed up to room temperature and was stirred for another hour. The reaction was quenched with aqueous $1 \mathrm{M} \mathrm{HCl}(70 \mathrm{~mL})$ and extracted three times with $\mathrm{Et}_{2} \mathrm{O}$. The combined organic extracts were washed with saturated aqueous $\mathrm{NaHCO}_{3}$, brine, and dried over $\mathrm{MgSO}_{4}$. Upon evaporation of the solvent, the product was purified via flash column chromatography on silica gel $(\mathrm{DCM} /$ hexanes $=1 / 1) \cdot 1$,3-Dichloro-2-phenylpropan-2-ol was furnished in $92 \%$ yield (14.87 g, $72.51 \mathrm{mmol})$.

$\mathbf{R}_{\boldsymbol{f}} \sim 0.35$ in DCM/hexanes (1/1)

${ }^{1} \mathrm{H}$ NMR $\left(500 \mathrm{MHz}, \mathrm{CDCl}_{3}\right) \delta 7.50(\mathrm{~m}, 2 \mathrm{H}), 7.41(\mathrm{~m}, 2 \mathrm{H}), 7.36(\mathrm{~m}, 1 \mathrm{H}), 3.98(\mathrm{~d}, J=11.6$ 
$\mathrm{Hz}, 2 \mathrm{H}), 3.93(\mathrm{~d}, \mathrm{~J}=11.6 \mathrm{~Hz}, 2 \mathrm{H}), 2.89(\mathrm{~s}, \mathrm{OH})$.

${ }^{13} \mathrm{C}$ NMR $\left(125 \mathrm{MHz}, \mathrm{CDCl}_{3}\right) \delta 140.2,128.7,128.5,125.8,75.6,50.8$.

Synthesis of 1,3-bis(tert-butylthio)-2-phenylpropan-2-ol<smiles>CC(C)(C)SCCC(O)(CSC(C)(C)C)c1ccccc1</smiles>

1,3-Dichloro-2-phenylpropan-2-ol $(6.17 \mathrm{~g}, 30.1 \mathrm{mmol})$ was added to a suspension of $\mathrm{K}_{2} \mathrm{CO}_{3}(20.79 \mathrm{~g}, 150.4 \mathrm{mmol})$ in DMF (100 mL). tert-Butylthiol $(10.85 \mathrm{~g}, 120.3 \mathrm{mmol})$ was added under Ar and stirred overnight. The reaction mixture was diluted with water and extracted three times with DCM. The combined organic extracts were washed with water and dried over $\mathrm{MgSO}_{4}$. After concentration in vacuo, the product was passed through a silica plug $(\mathrm{DCM} /$ hexanes $=1 / 1)$ to obtain pure 1,3-bis(tert-butylthio)-2-phenylpropan-2ol in $98 \%$ yield $(8.82 \mathrm{~g}, 28.3 \mathrm{mmol})$.

$\mathbf{R}_{\boldsymbol{f}} \sim 0.67$ in EtOAc/hexanes (1/6)

${ }^{1} \mathrm{H}$ NMR $\left(500 \mathrm{MHz}, \mathrm{CDCl}_{3}\right) \delta 7.49(\mathrm{~m}, 2 \mathrm{H}), 7.36(\mathrm{~m}, 2 \mathrm{H}), 7.28(\mathrm{~m}, 1 \mathrm{H}), 3.45(\mathrm{br}, \mathrm{OH}), 3.18$ (d, $J=12.4 \mathrm{~Hz}, 2 \mathrm{H}), 3.06(\mathrm{~d}, J=12.4 \mathrm{~Hz}, 2 \mathrm{H}), 1.31(\mathrm{~s}, 18 \mathrm{H})$.

${ }^{13} \mathrm{C}$ NMR $\left(125 \mathrm{MHz}, \mathrm{CDCl}_{3}\right) \delta 144.9,128.3,127.4,125.5,74.3,42.6,40.8,31.0$.

Synthesis of 4-hydroxy-4-phenyl-1,2-dithiolane (PhDL)<smiles>OC1(c2ccccc2)CSSC1</smiles>

Silica gel $(33.00 \mathrm{~g})$ was stirred with deionized water $(16.50 \mathrm{~mL})$ until a free-flowing powder was obtained. 1,3-Bis(tert-butylthio)-2-phenylpropan-2-ol (8.24 g, $26.4 \mathrm{mmol})$ in DCM 
(500 mL) was added, and $\mathrm{Br}_{2}(5.50 \mathrm{~g}, 34.3 \mathrm{mmol})$ in $\mathrm{DCM}(35 \mathrm{~mL})$ was slowly added dropwise until a light brown color persisted in the reaction mixture. The solution was then passed through a silica plug, and after concentration in vacuo, the product was loaded onto a silica gel column in hexanes and purified via flash column chromatography $\left(\mathrm{Et}_{2} \mathrm{O} / \mathrm{hexanes}=1 / 10\right)$ to obtain the pure compound in $77 \%$ yield $(4.02 \mathrm{~g}, 20.3 \mathrm{mmol})$. $\mathbf{R}_{\boldsymbol{f}} \sim 0.54$ in EtOAc/hexanes (1/6)

${ }^{1} \mathrm{H}$ NMR $\left(500 \mathrm{MHz}, \mathrm{CDCl}_{3}\right) \delta 7.59(\mathrm{~m}, 2 \mathrm{H}), 7.40(\mathrm{~m}, 2 \mathrm{H}), 7.33(\mathrm{~m}, 1 \mathrm{H}), 3.50(\mathrm{~d}, J=11.5$ $\mathrm{Hz}, 2 \mathrm{H}), 3.48(\mathrm{~s}, \mathrm{OH}), 3.27(\mathrm{~d}, \mathrm{~J}=11.5 \mathrm{~Hz}, 2 \mathrm{H})$.

${ }^{13} \mathrm{C}$ NMR $\left(125 \mathrm{MHz}, \mathrm{CDCl}_{3}\right) \delta 140.2,128.7,128.0,125.2,85.3,52.5$.

Synthesis of 4-acrylate-4-phenyl-1,2-dithiolane (PhDLA)<smiles>C=CC1(c2ccccc2)CCSC1</smiles>

PhDL (0.78 g, $3.9 \mathrm{mmol})$, TEA (1.98 g, $19.6 \mathrm{mmol})$, DMAP (0.09 g, $0.78 \mathrm{mmol})$, and a small spatula tip of phenothiazine (as radical inhibitor) were dissolved in dry THF (16 mL). Under Ar, acryloyl chloride (1.77 g, $19.6 \mathrm{mmol})$ was added dropwise. After $1 \mathrm{~h}$ of stirring, the reaction mixture was heated to $50^{\circ} \mathrm{C}$ and stirred for another $12 \mathrm{~h}$. The reaction mixture was diluted with $\mathrm{DCM}$ and washed with $1 \mathrm{M} \mathrm{HCl}$, saturated aqueous $\mathrm{NaHCO}_{3}$, and brine. After drying over $\mathrm{MgSO}_{4}$ and evaporation of the solvent, PhDLA was purified via flash column chromatography on silica gel $(\mathrm{DCM} /$ hexanes $=1 / 2)$ to obtain the pure compound in $46 \%$ yield $(0.46 \mathrm{~g}, 1.8 \mathrm{mmol})$.

$\mathbf{R}_{\boldsymbol{f}} \sim 0.51$ in DCM/hexanes (1/1)

${ }^{1} \mathrm{H}$ NMR $\left(500 \mathrm{MHz}, \mathrm{CDCl}_{3}\right) \delta$ 7.38-7.27 (m, 5H), $6.45(\mathrm{dd}, J=17.33$ and $1.3 \mathrm{~Hz}, 1 \mathrm{H})$, $6.21(\mathrm{dd}, J=17.3$ and $10.4 \mathrm{~Hz}, 1 \mathrm{H}), 5.90(\mathrm{dd}, J=10.4$ and $1.3 \mathrm{~Hz}, 1 \mathrm{H}), 3.80(\mathrm{~d}, J=12.8$ $\mathrm{Hz}, 2 \mathrm{H}), 3.71(\mathrm{~d}, J=12.8 \mathrm{~Hz}, 2 \mathrm{H})$. 
${ }^{13} \mathrm{C}$ NMR $\left(125 \mathrm{MHz}, \mathrm{CDCl}_{3}\right) \delta 164.9,140.9,132.0,128.9,128.6,128.1,125.6,93.7,52.0$. HRMS (ESI-TOF): Calculated for $\left[\mathrm{M}+\mathrm{NH}_{4}\right]^{+}$requires 270.0617; found 270.0612

Synthesis of 4-isobutyryl-4-phenyl-1,2-dithiolane (iBuPhDL)

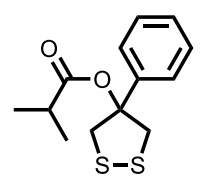

PhDL (0.10 g, $0.50 \mathrm{mmol})$, TEA (0.20 g, $2.0 \mathrm{mmol})$, and DMAP (0.02 g, $2.0 \mathrm{mmol})$ were dissolved in dry THF (3 mL). Under Ar, isobutyryl chloride $(0.22 \mathrm{~g}, 2.0 \mathrm{mmol})$ was added dropwise. After $1 \mathrm{~h}$ of stirring, the reaction mixture was heated to $50{ }^{\circ} \mathrm{C}$ and stirred for another $12 \mathrm{~h}$. The reaction mixture was diluted with DCM and washed with $1 \mathrm{M} \mathrm{HCl}$, saturated aqueous $\mathrm{NaHCO}_{3}$ and brine. After drying over $\mathrm{MgSO}_{4}$ and evaporation of the solvent, $\mathrm{iBuPhDL}$ was purified via flash column chromatography on silica gel $\left(\mathrm{Et}_{2} \mathrm{O} /\right.$ hexanes $\left.=1 / 10\right)$ to obtain the pure compound in $95 \%$ yield $(0.13 \mathrm{~g}, 0.48 \mathrm{mmol})$.

$\mathbf{R}_{\boldsymbol{f}} \sim 0.51$ in DCM/hexanes (1/1)

${ }^{1} \mathrm{H}$ NMR $\left(500 \mathrm{MHz}, \mathrm{CDCl}_{3}\right) \delta 7.37-7.27(\mathrm{~m}, 5 \mathrm{H}), 3.75(\mathrm{~d}, J=12.7 \mathrm{~Hz}, 2 \mathrm{H}), 3.66(\mathrm{~d}, J=$ 12.7 Hz, 2H), 2.65 (sept, $J=6.9 \mathrm{~Hz}, 1 \mathrm{H}), 1.21(\mathrm{~d}, J=7.0 \mathrm{~Hz}, 6 \mathrm{H})$.

${ }^{13} \mathrm{C}$ NMR $\left(125 \mathrm{MHz}, \mathrm{CDCl}_{3}\right) \delta 175.7,141.0,128.8,128.1,124.5,92.9,51.5,34.5,19.0$. HRMS (ESI-TOF): Calculated for [M+Na] ${ }^{+}$requires 291.0498; found 291.0498.

\section{Gelation of PEG-PhDL under UV light}

In a $20 \mathrm{~mL}$ glass vial $(25 \mathrm{~mm}$ diameter) capped with a rubber septum, PEG-PhDL (50.0 $\mathrm{mg}$ ) was dissolved in water ( $0.45 \mathrm{~g}, \mathrm{HPLC}$ grade). The viscous solution was purged for 7 min with Ar and irradiated with UV light $\left(\lambda_{\max }=365 \mathrm{~nm}, 2.5 \mathrm{~cm}\right.$ distance from the light source) to yield a transparent hydrogel. 
Investigation of PEG-PhDL photolysis in water

In a $10 \mathrm{~mL}$ Schlenk flask, PEG-PhDL (40 mg) was dissolved in water (1.96 g, HPLC grade) yielding a $2 \mathrm{wt} \%$ solution. After purging for $10 \mathrm{~min}$, the solution was irradiated with UV light $\left(\lambda_{\max }=365 \mathrm{~nm}, 2.5 \mathrm{~cm}\right.$ distance from the light source) and aliquots were withdrawn in regular time intervals for UV-vis analysis (Figures $3 \mathrm{C}$ and S10).

\section{Ellman's assay on PEG-PhDL gels}

$0.5 \mathrm{~mL}$ of Ellman's reagent solution ( $10 \mathrm{mM}$ in $\mathrm{pH} 8$ phosphate buffer) were added to UVcured PEG-PhDL hdyrogels after $0,1,2,5$, and $10 \mathrm{~min}$ of UV irradiation. After 5 min incubation time, the supernatant was pipetted off and analyzed via UV-vis (Figures 5C and S16).

Gelation of PEG-PhDL under green light open to air

In a $20 \mathrm{~mL}$ glass vial $(25 \mathrm{~mm}$ diameter) PEG-PhDL $(50.0 \mathrm{mg})$ was dissolved in water (0.45 mL, HPLC grade). EY $(0.18 \mathrm{mg})$ was added and the mixture was vortexed until a homogeneous solution was obtained. Network formation occurred upon irradiation with green light $\left(\lambda_{\max }=515 \mathrm{~nm}, 2.5 \mathrm{~cm}\right.$ distance from the light source).

Note: Assuming 68\% 1,2-dithiolane incorporation gives a theoretical PEG-PhDL molecular weight of $9870 \mathrm{~g} / \mathrm{mol}$ with 5.4 1,2-dithiolane units per polymer chain. Consequently, there are $0.005 \mathrm{mmol}$ PEG-PhDL in $50.0 \mathrm{mg}$, corresponding to 0.027 mmol of 1,2-dithiolane units. $0.18 \mathrm{mg} \mathrm{EY}$ are $0.27 \mu \mathrm{mol}$, which equals 0.01 molar equivalents with respect to 1,2-dithiolane units.

\section{Rhodamine $6 \mathrm{G}$ release from UV-cured gels}

In a $20 \mathrm{~mL}$ glass vial (25 mm diameter) capped with a rubber septum, PEG-PhDL (50.0 
$\mathrm{mg}$ ) was dissolved in water (0.45 g, HPLC grade). Rhodamine 6G $(1.0 \mathrm{mg})$ was added and the mixture was vortexed until a homogeneous solution was obtained. The solution was purged with Ar for 7 min and irradiated with UV light $\left(\lambda_{\max }=365 \mathrm{~nm}, 2.5 \mathrm{~cm}\right.$ distance from the light source) to yield a deep red hydrogel (Figure 7). The gel was cut into three pieces (150 mg each) and one piece was immersed into water (10 mL), one into aqueous MSH solution (10 mL, $9 \mu \mathrm{M})$, and one into aqueous DTT solution (10 ml, $9 \mu \mathrm{M})$. Aliquots were withdrawn from the supernatants after regular time intervals for UV-vis analysis. The fractional "dye-release" was calculated by dividing the absorbance of the respective aliquot at $527 \mathrm{~nm}$ (i.e., $\lambda_{\max }$ for rhodamine $6 \mathrm{G}$ ) by the absorbance value at that wavelength after complete hydrogel disintegration. 
S6. Supplementary NMR Spectra

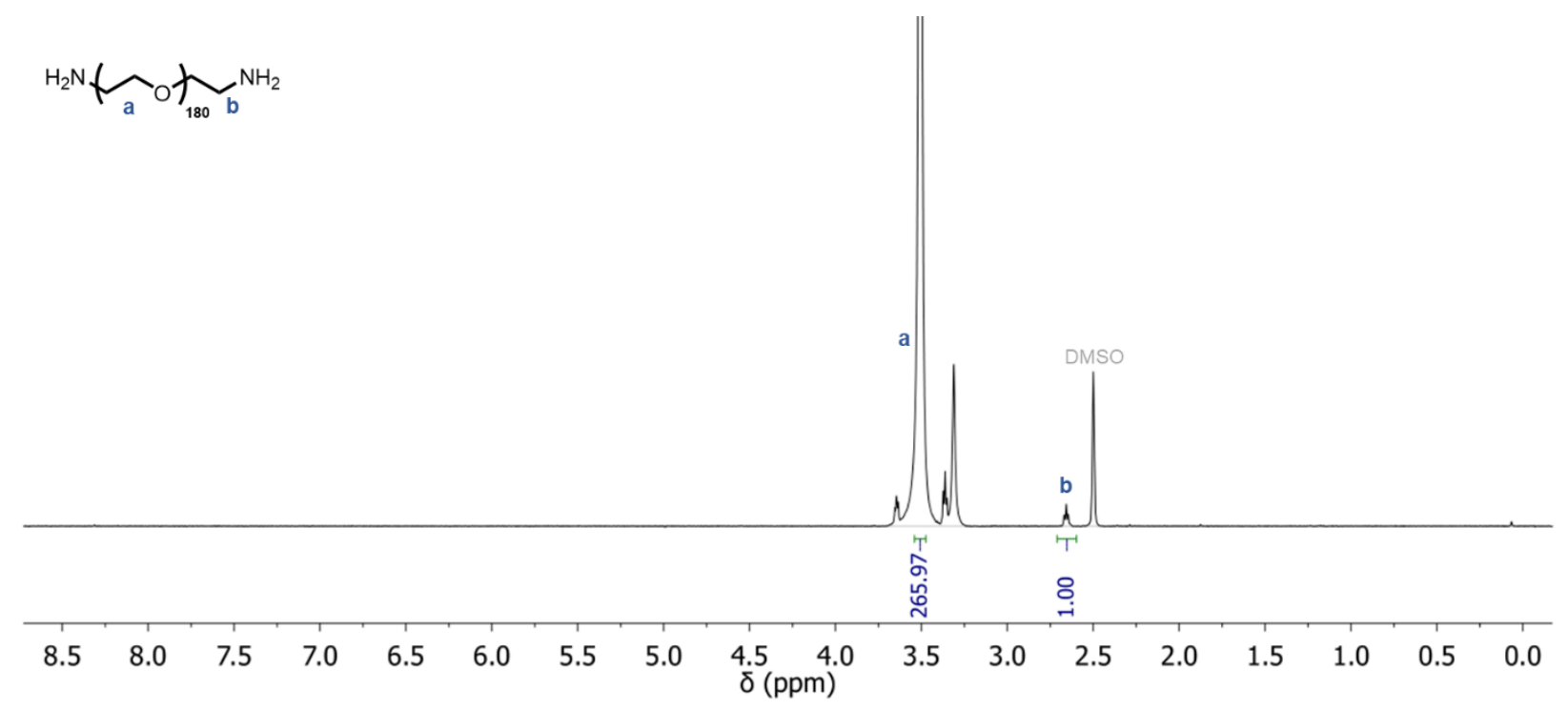

Figure S24. ${ }^{1} \mathrm{H}$ NMR spectrum of PEG-NH$H_{2}$ in DMSO- $d_{6}$.
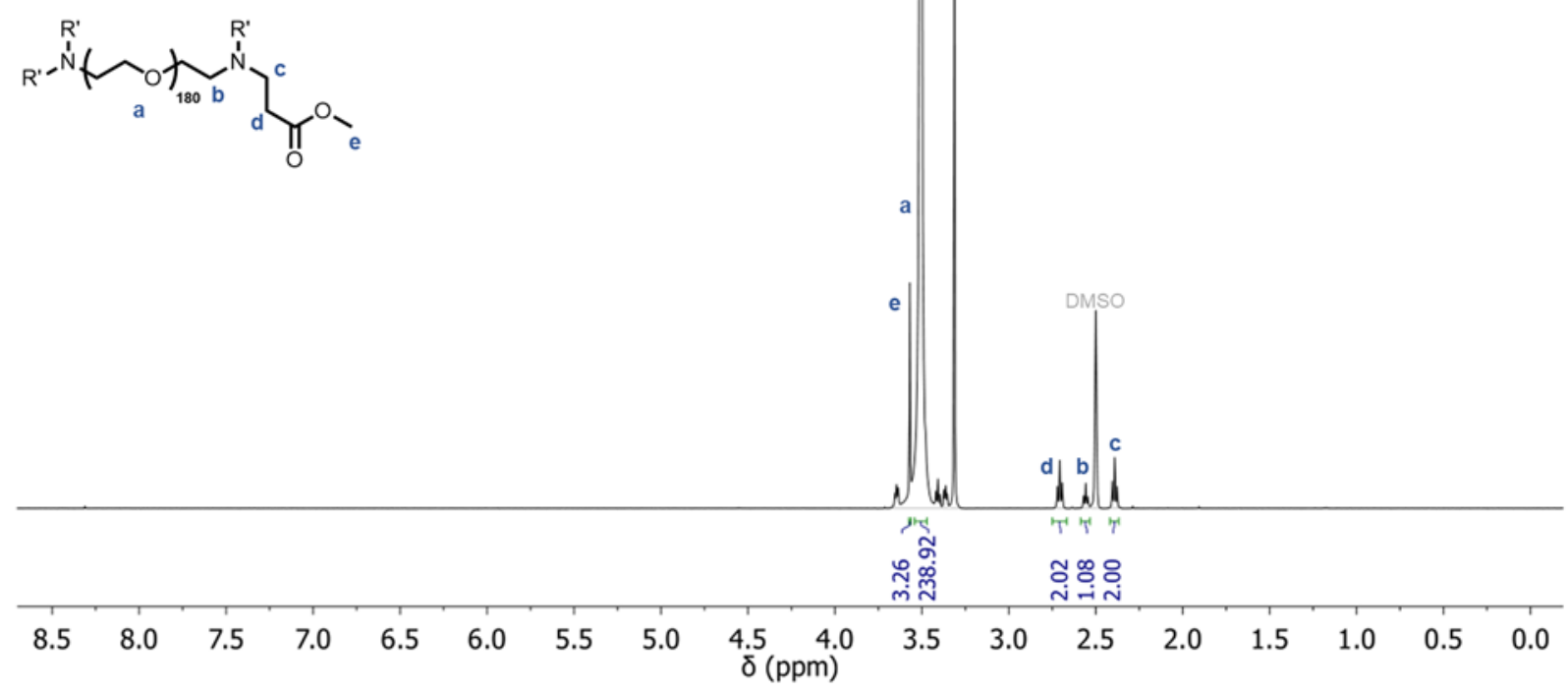

Figure S25. ${ }^{1} \mathrm{H}$ NMR spectrum of PEG 0.5 in DMSO- $d_{6}$. 

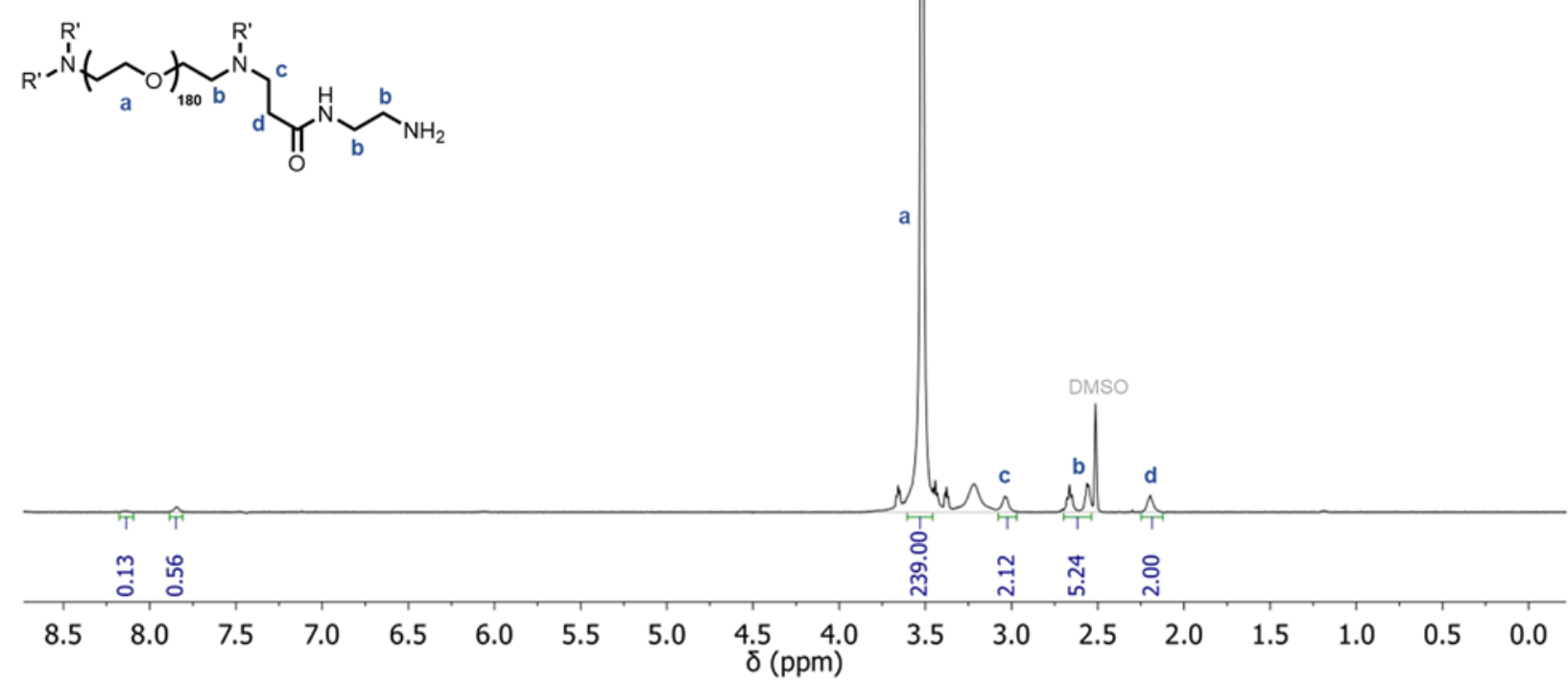

Figure S26. ${ }^{1} \mathrm{H}$ NMR spectrum of PEG 1.0 in DMSO-d.
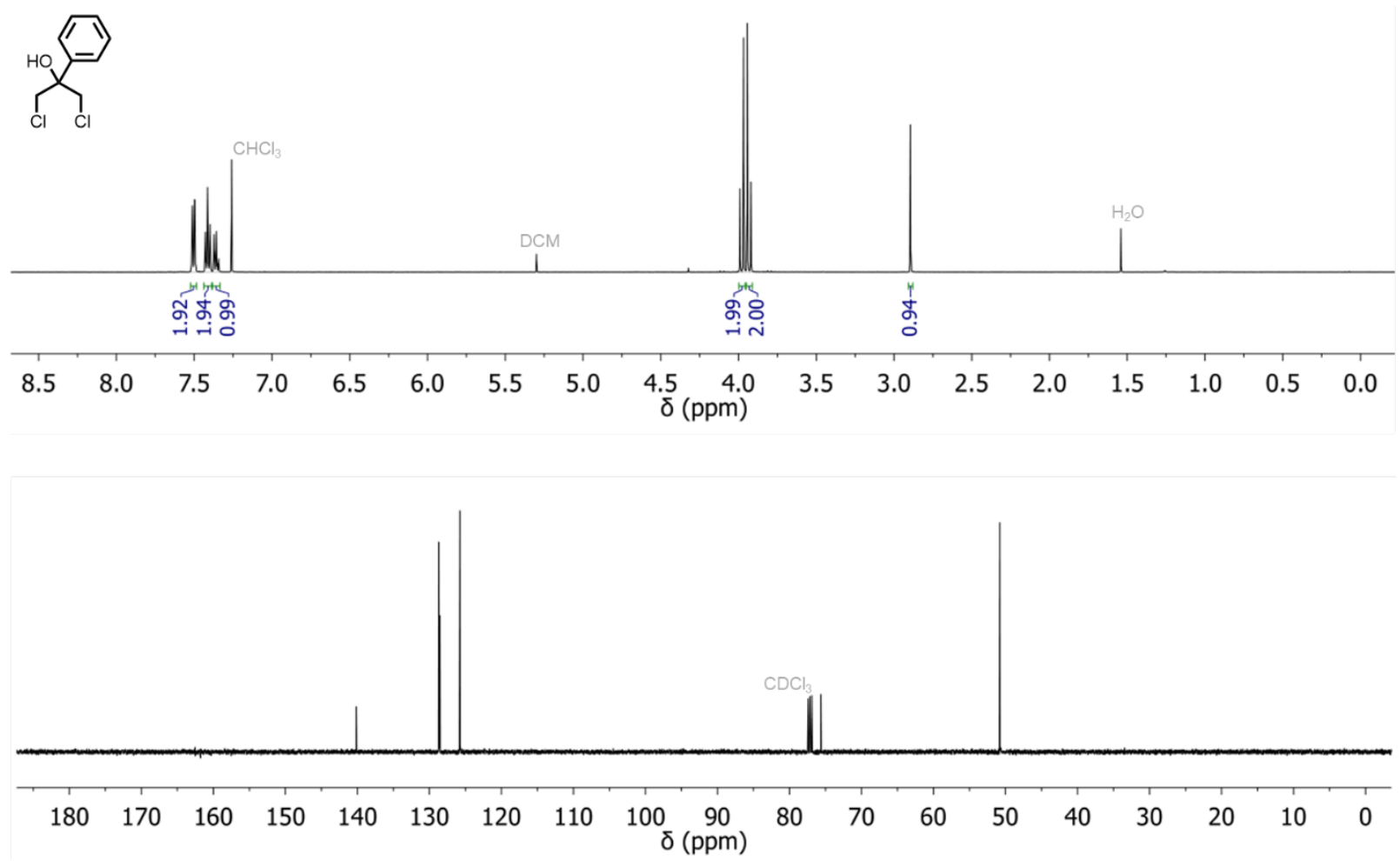

Figure S27. ${ }^{1} \mathrm{H}$ and ${ }^{13} \mathrm{C}$ NMR spectrum of 1,3-dichloro-2-phenylpropan-2-ol in $\mathrm{CDCl}_{3}$. 


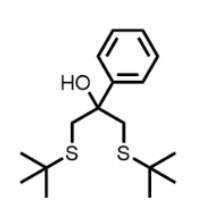
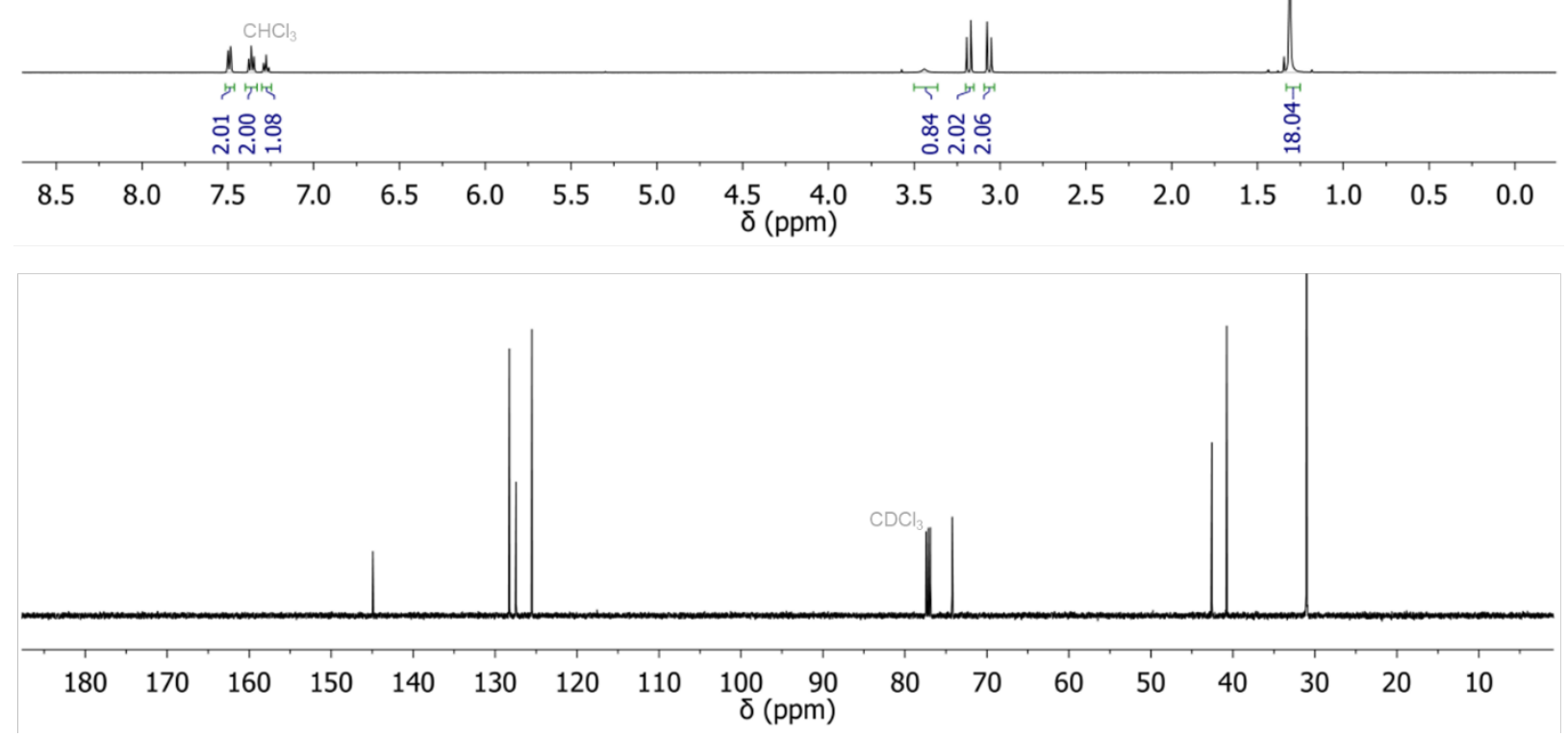

Figure S28. ${ }^{1} \mathrm{H}$ and ${ }^{13} \mathrm{C}$ NMR spectrum of 1,3-bis(tert-butylthio)-2-phenylpropan-2-ol in $\mathrm{CDCl}_{3}$.
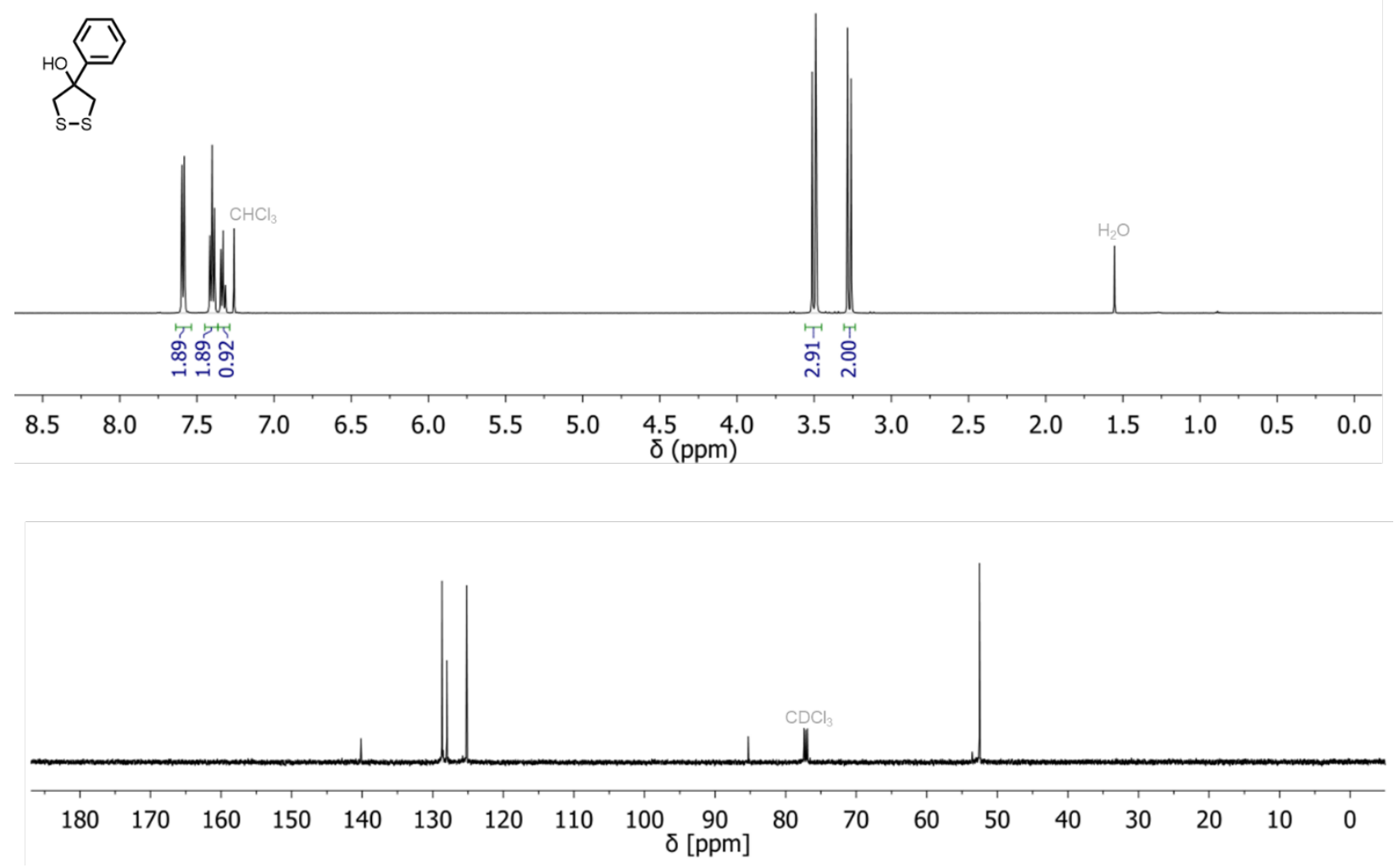

Figure S29. ${ }^{1} \mathrm{H}$ and ${ }^{13} \mathrm{C}$ NMR spectrum of $\mathrm{PhDL}$ in $\mathrm{CDCl}_{3}$. 

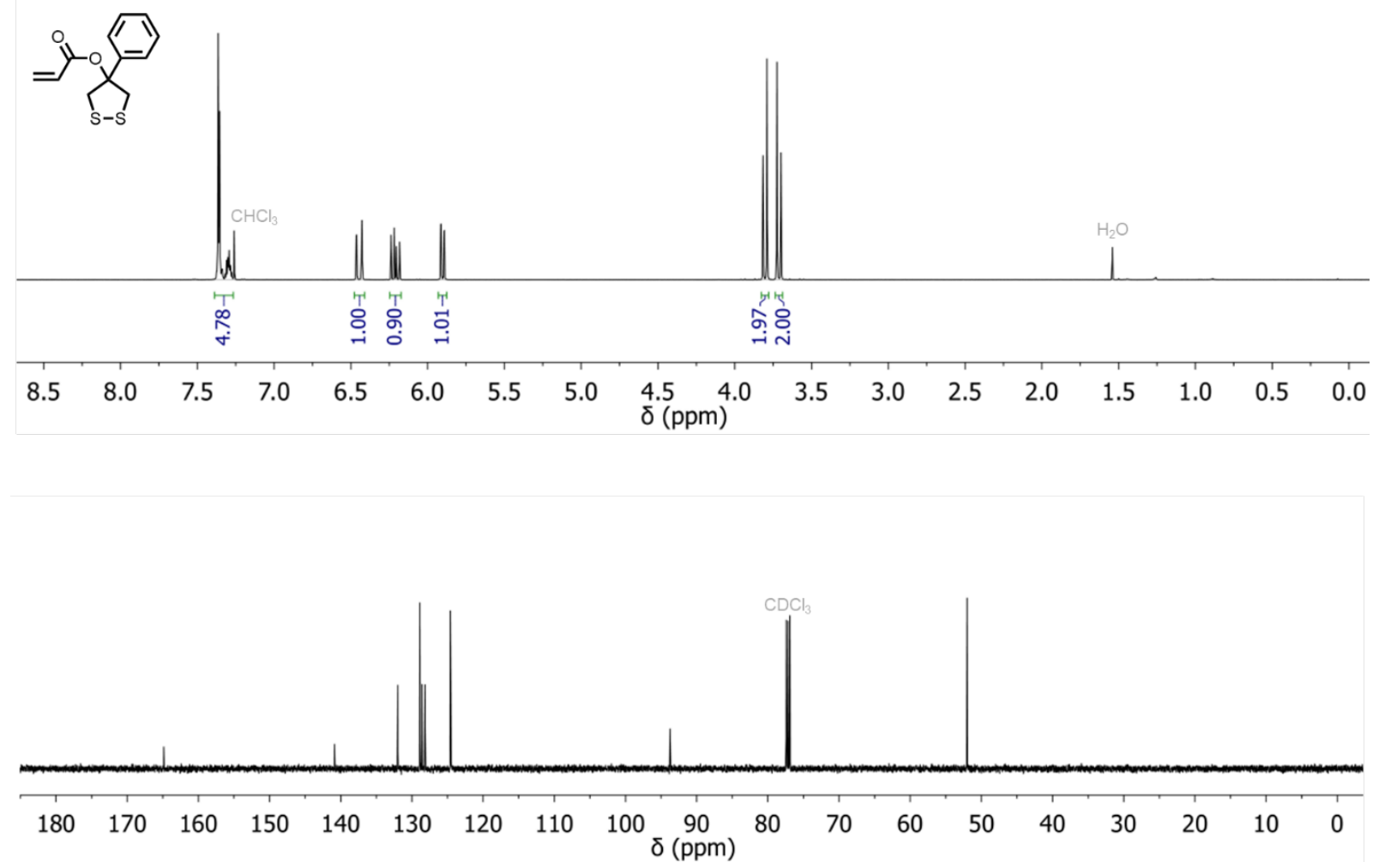

Figure S30. ${ }^{1} \mathrm{H}$ and ${ }^{13} \mathrm{C}$ NMR spectrum of PhDLA in $\mathrm{CDCl}_{3}$. 

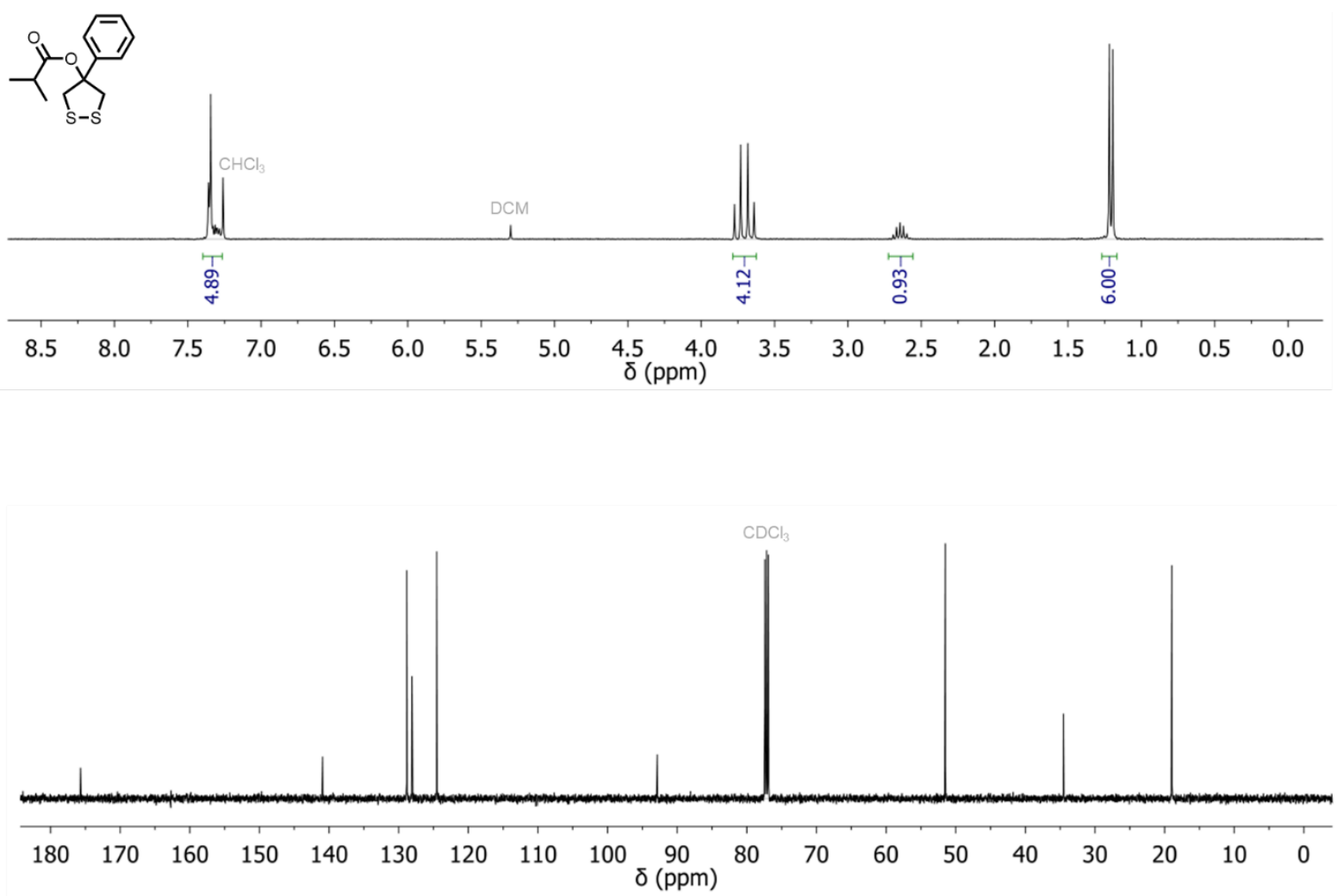

Figure S31. ${ }^{1} \mathrm{H}$ and ${ }^{13} \mathrm{C}$ NMR spectrum of $i \mathrm{BuPhDL}$ in $\mathrm{CDCl}_{3}$.

\section{S7. References}

(1) Ali, M. H.; McDermott, M. Oxidation of thiols to disulfides with molecular bromine on hydrated silica gel support. Tetrahedron Lett. 2002, 43, 6271-6273.

(2) Arrington, K. J.; Matson, J. B. Assembly of a visible light photoreactor: an inexpensive tool for bottlebrush polymer synthesis via photoiniferter polymerization. Polym. Chem. 2017, 8, 7452-7456.

(3) Bagotsky, V. S. Electrode Potentials. Fundamentals of Electrochemistry, John Wiley \& Sons: Hoboken, New Jersey, 2006; pp 19-31.

(4) Humphrey, R. E.; Potter, J. L. Reduction of Disulfides with Tributylphosphine. Anal. Chem. 1965, 37, 164-165.

(5) Vasudevan, D.; Wendt, H. Electroreduction of oxygen in aprotic media. J. Electroanal. Chem. 1995, 392, 69-74.

(6) Abegg, D.; Gasparini, G.; Hoch, D. G.; Shuster, A.; Bartolami, E.; Matile, S.; Adibekian, A. Strained Cyclic Disulfides Enable Cellular Uptake by Reacting with the Transferrin Receptor. J. Am. Chem. Soc. 2017, 139, 231238.

(7) Macosko, C. W. Linear Viscoelasticity. Rheology: Principles, Measurements, and Applications. Wiley-VCH: New York, 1994; pp 122-123.

(8) Goodwin, J. W.; Hughes, R. W. Linear Viscoelasticity I: Phenomenological Approach. Rheology for Chemists: An Introduction. 2 ed.; Royal Society of Chemistry: Cambridge, 2008; pp 102-103. 